\title{
Persuasive system features in computer-mediated lifestyle modification interventions for physical activity
}

Khin Than Win, Harri Oinas-Kukkonen, Madeleine R H Roberts

Running title: Persuasive Physical

Keywords:

Persuasive technology, behaviour change support systems, tailoring, reminders, physical activity 


\title{
Persuasive system features in computer-mediated lifestyle modification interventions for physical activity
}

\begin{abstract}
Objective:

Increasing physical activity has been identified as one of the most important factors in lifestyle modification. Previous studies have reported the effectiveness of using the Internet in motivating behavioural modifications of physical activities. The aim of this study is to identify the persuasive system features most frequently used in computermediated physical activities in the current literature.
\end{abstract}

\section{Materials and Method}

In this review, intervention studies were identified through a structured computerised search of PubMed, PsychInfo, and Web of Science. The results of the search were analysed using the Persuasive Systems Design (PSD) features identified by OinasKukkonen and Harjumaa (2009).

\section{Results}

Thirty-eight articles were reviewed and the features of the physical activity interventions described were mapped to the identified facets of Persuasive Systems Design (PSD). The PSD features used most often by researchers in the studies considered in this research included: tailoring; tunnelling; reminders; trustworthiness; and expertise. The effectiveness of the interventions described in the studies was also compared. The stage of change theory was applied in several intervention studies and the importance of stage of change has been identified in effectiveness of persuasion towards physical activity.

Research highlights

- The persuasive systems design features commonly present in physical activity intervention studies were identified.

- The tailoring, tunneling, reminders, trustworthiness and expertise features were used more frequently than others in promoting health behaviour change to increase physical activity.

- The tailoring feature was frequently used in conjunction with features from the dialogue support category to encourage physical activity in online applications.

- The social support category was not discussed widely in physical activity intervention studies.

- The effectiveness of computer-mediated lifestyle modification interventions for physical activity was gauged. 


\section{Persuasive system features in computer-mediated lifestyle modification interventions for physical activity}

\section{Background}

"Prevention of chronic disease has become a priority in the healthcare industry" $(1,2)$.

One of the key aspects - and a dilemma - in minimising the risk factors for chronic diseases is how to motivate people to modify their lifestyle (3). Increasing physical activity has been identified as one of the most important factors in lifestyle modification; among others such as balanced nutrition, smoking cessation, and reduction in alcohol intake. Previous studies have reported on the effectiveness of online self-management in behavioural modifications (4-6) such as a self-monitoring program for people living with HIV/AIDS (7), a burns self-management education program (8), a diabetes selfmanagement education program (9) and an asthma self-management program (10). There is evidence supporting the contention that online health information provision, education and management have both health and social benefits for health consumers $(6,11)$. Studies also indicate that interactive computing could change consumers' attitudes and behaviour with regard to their healthcare management (12).

Several studies have described how behaviour change support could be implemented to improve health management (13-16). Behaviour change support systems are defined as "socio-technical information systems with psychological and behavioral outcomes designed to form, alter or reinforce attitudes, behaviours or an act of complying without using coercion or deception" (17) and such systems must be persuasive in nature; employing computer-human persuasion or computer-mediated persuasion. 
As the intent of behaviour change is to influence users, it is important to identify the design features in these systems that elicit the desired outcomes. Since context always plays an important role in persuasion, each event of persuasion should be designed after identifying the problem domain as well as the attitude, behaviour motivation of the intended users, and the technology-dependent features $(14,18)$.

The aim of this study is to identify the persuasive features most frequently used in the design of physical activity interventions. A literature review was conducted to identify the Persuasive Systems Design (PSD) features (19).

\subsection{Persuasive systems design}

Over the years, models and theories of persuasion have been posited in an effort to identify its characteristics. The Elaboration Likelihood Model explains the effectiveness of persuasive communications by describing it as a dual process involving a central and peripheral "route" (20). Using this model of persuasion in a behavioural change design, text messages could be provided as the central route to assist in critical thinking, with information presentation as the peripheral route (21). Persuasive systems that mimic or extend the patient-provider communication would be likely to assist in the process of behavioural change (14). Social Support theory also indicates that social support can influence the health and well-being of individuals (22). Several researchers have studied the concept of tailoring a system according to the user's needs $(8,11,23,24)$, providing interactivity with the system for better communication (25-27), and social support (28, 29) to assist patients' behavioural change. Michie et al. (2013) identified a behaviour 
change taxonomy which included a number of facets such as "scheduled consequences", "reward and threat", "repetition and substitution", "antecedents, associations", "covert learning", "natural consequences", "feedback and monitoring", "goals and planning", "information about others' approval", "self belief", "comparison of outcomes", "identity", "shaping knowledge and regulation" (30). Various studies have adopted behaviour change perspectives based on different theoretical philosophies. Of these, Social Cognitive Theory has been strongly favoured in behaviour change studies (31) with goal-setting being a key strategy for behaviour change (31). While providing information is important, including an attainable goal for behaviour change to enhance personal motivation is also regarded as an essential ingredient. Additionally, social motivation should be provided in behaviour change interventions. Goal-setting can be self-set, assigned or collaborative $(32,33)$. Therefore, including goal-setting, having an attainable goal, conducting self-monitoring and providing feedback have been recognised as requirements for behaviour change support (34). Fogg (2003) identified recognised that computers could act as tools, social actors and media for persuasion; leading to behaviour change (12). From this perspective, technology-assisted health behaviour change support systems need to provide behaviour change techniques such as goalsetting, self-monitoring, feedback, reinforcement (35), and social support (18). Previous studies also have reviewed behavior change techniques for different health domain (36). The Persuasive Systems Design (PSD) model has been developed to assist in both designing and evaluating systems that influence the attitudes or behaviours of users (19) and has been validated in previous studies $(37,38)$. The model defines seven postulates which need to be addressed when designing or evaluating persuasive systems. These key 
premises relate to the users of persuasive systems, persuasion strategies, and system features. The system features are divided into four categories: primary task support; dialogue support; system credibility support; and social support. In addition to this, the model defines twenty-eight design guidelines, which are subdivisions of the four categories. These guidelines describe system features that will improve the persuasiveness of a system. These features are presented in Table 1 .

Insert Table 1 here.

\section{Methodology}

\subsection{Search Strategy and Data Sources}

In this review, intervention studies were identified through a structured computerised search of PubMed, PsychInfo, and Web of Science. The search terms used were (exercise OR motor activity OR sports OR leisure activities) OR (physical* AND active) OR (physical* AND activity) OR (physical* AND activities) OR exercis* OR walking OR cycling OR sport* OR leisure activit* AND (education OR behavior OR behavio* OR education) AND (tailored OR tailoring OR tailor* OR expert system). To identify the delivery platforms of interest, the following search terms were added: (web* OR computer* OR internet* OR online OR mobile OR mHealth OR digital OR technology). No limitations for age of participants or study design were added, however the studies considered were confined to those targeting physical activity to improve user's health. 


\subsection{Selection of Studies}

The studies selected for this review had to examine a computer-based intervention aimed at promoting healthy physical activity as a means of preventing potentially chronic diseases. The selection criteria devised by the authors determined that the platform for the intervention could be either a static or a mobile computing device and delivery could be via an application or a browser. The search terms were used to identify potential studies in three databases: PubMed, PsychInfo and Web of Science. One of the authors searched these databases and exported the results to an Endnote file. Two authors independently assessed the suitability of the articles and discussed the results after every stage of the filtering process. The elimination process is depicted in Figure 1.

Insert Figure 1 here.

Figure 1: Flow Chart of Database Search

Inclusion and Exclusion criteria

Inclusion criteria

- Studies need to meet following criteria to be included in the review

- A peer reviewed article, written in English

- Paper focuses on lifestyle modification of physical activity.

\section{Exclusion criteria}


- Papers focused on other behavioural change activities such as smoking cessation, medication management, and alcohol consumption

- Studies on continuing medical education for health professionals

- Articles that are not consumer-centric

- Disease specific studies, which are not related to physical activities

- Intervention studies on physical activity change that do not use any form of information technology

- Reviewed articles.

\subsection{Data Extraction}

Detailed information was extracted only from studies that met the aforementioned criteria for inclusion and exclusion. Two authors were involved in the data extraction process. After the final 38 articles were identified, the three authors reviewed the articles and coded them on an Excel spreadsheet according to the definitions of the 28 design features identified in the PSD (19). Any differences in the coding were discussed and a second round of coding was conducted. The final mapping was based on the agreement of at least two (of the three) authors. Articles were also categorised based on the study type. Those studies that conducted a randomised controlled trial were further assessed to determine which behaviour change techniques had been utilised and what outcome or outcomes had been achieved. 


\section{Results}

\subsection{Study selection}

The initial cross-database search resulted in 981 articles. Titles and abstracts were reviewed further for specific eligibility criteria, resulting in 173 papers that were fully considered. Of those, thirty-eight were eventually included: 24 of those studies involved a web-based application; 5 used a combined web and SMS or app intervention approach; and 4 studies focused on an SMS intervention. The remainder of the studies used specialised equipment such as accelerometers or technology specifically designed for the intervention. Of the total, twelve papers discussed studies conducted in the USA, seven in Australia, five in the Netherlands, three in Belgium, two studies from Denmark, and one study each from Germany, Hong Kong, Iran, Korea, Norway and the UK. Two studies included international studies, which covered (i) Canada and London and (ii) Germany and the Netherlands. The participants involved in the studies varied from school aged children to adults.

Insert Table 2 here.

Insert Table 3 here.

\subsection{Persuasive Systems Design}

\subsubsection{Primary task support}


Computer-mediated persuasion has been identified by the authors of the reviewed papers as a means to motivate and assist users to perform the required tasks. As the reviewed articles were focused on motivating users to be physically active and encouraging users to continue using the system, the primary task support features of the PSD model (19) were present in many of these systems. Reduction $(n=22)$, tunnelling $(n=27)$, tailoring $(n=33)$ and self-monitoring $(n=24)$ were frequently noted in these articles. However, not all persuasive features are present in all the systems reviewed. Tailoring ( $\mathrm{n}=33$ ) was present in the majority of the systems described in the articles included in this review. The results of this review suggest that tailoring could be grouped with goal-setting, that is: allowing the users to choose from a set of options after giving them the available information or after using a questionnaire to profile the users $(39,40)$. Tailored activity and action plans were presented to users based on answers to the physical activity and psychosocial questionnaires assessment in one study (41). The reduction and tunnelling features are incorporated when a tailoring intervention has been provided; as tailored information or providing an activity would reduce user effort and bring them to the targeted behaviour. Dour et al. (2013) also suggested gender-tailored motivation as there are different health motivators for men and women (42). Step wise goal-setting was provided to participants in "Guide to Health Program" (43). Physical activity advice is tailored according to the patients' stage of change in the study conducted in Australia to promote physical activity for different age groups (39).

The reduction feature was presented in physical activity interventions to assist users. The "COMPASS" study provides an Embodied Conversational Agent with which users can 
interact, simply by touching the screen (44). Similarly, an interactive application such as Google Maps is made available to users to provide them with a navigational path (45).

The tunnelling feature was identified in many of the reviewed articles which described systems that provided tailored information based on the results of an assessment conducted on an individual user (46).

Kaptein et al. (2015) identified personalisation as both an explicit and implicit method (14). This would be achieved through explicit profiling, as tailored physical activities would be provided after answering a questionnaire, while implicit profiling would utilise the user's profile, behaviour and data from the user's social networking. Both these methods have been coded under tailoring in this review as they provide tailored information to the users.

There are several self-monitoring tools available to encourage lifestyle modifications by consumers. Web-based self-monitoring systems have been developed and these systems encourage consumers to be involved in their own healthcare (47). Sixty three per cent (24 out of 38) of the articles in this review included self-monitoring functions for consumers. This feature is presented in the systems in a variety of forms such as users sending weekly self-monitoring data via their mobile phone (48) which will become the basis for the tailored messages that they receive about their lifestyle management. A health promotion program provided to high school students used interactive self-monitoring logs for exercise and weight management (49). A clinically-endorsed lifestyle support program developed for perinatal women included progress tracking through an interactive website and a smart phone app for self-monitoring (50), while participants in a Cardiofit activity were asked to log their daily activity on a dedicated website (51). 


\subsubsection{Dialogue support}

An important component in persuasive technology is the provision of an intervention similar to "human-to-human" interaction such as dialogue support $(14,52)$. Dialogue support must be designed according to the context in which it will be used. In a nutritional coach program, the dialogue support was designed to replicate the first session a client would have with a health advisor (53). Oinas-Kukkonen and Harjumaa (2009) identified seven features of dialogue support: praise, rewards, reminders, suggestion, similarity, liking and social role (19). Reminders and feedback in the form of praise and suggestion are essential components of effective healthcare management. Providing feedback has become an important aspect of online health interventions (54-56) since it is recognised that providing praise and rewards to users encourages them to continue modifying their behaviour. The articles included in this review indicated that positive feedback was provided to participants such as: badges being awarded for meeting the step goals, and paper walking shoes being presented when identified step goals were met (43). Motivational text messages were sent to participants in several studies $(48,57,58)$.

Researchers have recognised that reminders for health interventions enhance health promotion and adherence to the user's healthcare management guidelines $(59,60)$. Reminders prompt patients to perform the required task (61), hence they play a pivotal role in online health promotions and interventions. The studies examined in this review indicated that reminders $(n=30)$ had been provided via SMS (57), and by phone and email (62). 
The suggestion feature $(n=22)$ encourages users to carry out the desired behaviours (4). This feature was identified in the Healthy Weight Assistant Program in which users were coached to: set useful and realistic goals, (63); reflect on their achievement; and find solutions (63).

Oinas-Kukkonen and Harjumaa (2009), in discussing computer-human persuasion, stated that a virtual personal advisor could provide support (19). This social role feature $(n=7)$ was identifiable in some of the articles reviewed. In the "COMPASS" study, for example, a virtual advisor provided suggestions in English and Spanish about physical activity (44) and participants were encouraged to interact with the advisor on a weekly basis, or as frequently as they desired.

The similarity $(n=3)$ feature was not utilised in most of the reviewed articles. The computer-human persuasion can be constructed as the influence of peers to the user. For example, Lau et al. (2012), used SMS messages which had been sent by a peer of the participants because studies have indicated that adolescents prefer to receive support from others in their own age group (64). Other examples of computer-human support evident in the reviewed articles were features such as: a salutation and individualised social dialogue sent to users from a virtual avatar (44); feedback on the progress of each participant's lifestyle modifications in graphical formats $(43,65)$ or using a multimedia format such as videos (66).

The "Liking" feature could not be identified in the articles reviewed as this feature would be more evident in a review of the actual system, rather than in the intervention studies.

\subsubsection{System Credibility Support}


It has been noted that reliability, credibility, accessibility, and readability of information are among the main concerns consumers have regarding online health information (67) (68). Credibility of information has the potential to critically affect health outcomes for many users (69). Efforts have been made to establish the criteria required for high quality online health information such as the Health on the Net Code of Conduct and the ongoing work of the Health Summit Working Group (47). System credibility support in the PSD model (Oinas-Kukkonen \& Harjumaa, 2009) includes the facets of trustworthiness, expertise, surface credibility, real world feel, authority, third party endorsement and verifiability(19). The studies considered in this review have acknowledged that healthcare providers' advice to patients about targeted behaviour will be more effective (70) when there is obvious involvement of health professionals, so providing expert opinions will be beneficial to users of persuasive systems. The reviewed articles also indicated that trustworthiness $(n=33)$ and expertise $(n=31)$ had informed the design of the persuasive systems described. Most of the articles reviewed were studies of randomised controlled trials and interventions from health organisations and or based on clinical endorsement, thus, the credibility support features listed above have been covered. For example, in the "My Activity Coach" program the specific benefits of physical activity were sourced from the research findings of trusted organisations such as the World Health Organisation (40). Some systems provided expert advisers to users who were able to email an exercise specialist and ask questions about the program (41).

Other system credibility support facets, such as authority $(n=7)$, third party endorsements $(n=5)$ and verifiability $(n=6)$, were not mentioned as much as the trustworthiness and expertise features in the reviewed articles. It could be, however, that the actual 
application did have those features because the systems were supported by or developed and informed by a University hospital, health organisation or government-funded institution but these were not discussed in the papers this study reviewed.

Surface credibility and real world feel were also not noted as features of the systems described. This may have been because the reviewed papers were mainly focused on clinical trials, or the results of interventions, so the information architecture of the websites, or the medium used, were not discussed.

\subsubsection{Social support}

Social motivation is another means by which to steer people towards the targeted behaviour (3), so the system implemented should include social support. Social comparison, social learning, normative influence and social facilitation are facets of social support that will encourage users to adopt the targeted behaviour because they can observe others with the same characteristics perform the behaviour in a similar situation $(14,71)$. There were a few examples of social support being facilitated between participants such as the Rural Environment and Community Health (REACH) Program which implemented online forums where participants could provide peer support through sharing experiences and information $(62,72)$. Participants were also encouraged to interact with each other, sharing information among others in the SMART study conducted by Patrick et al. (2014) (72). Informal support of this type was also facilitated via an online expert system used by the Kaiser Permanente Integrated Healthcare program designed for weight management (73). Social support was provided to participants in a ManUp study where participants could create a group and provide support (74) . 
The social support category was one which was not frequently utilised, with facets such as cooperation $(n=4)$, competition $(n=1)$ and recognition $(n=1)$ almost unused; at least when compared to the other three categories of the PSD (19). It might be expected, however, that the uptake of this feature will increase with the growing adoption of mobile technologies and social applications in healthcare.

Combined Persuasive Systems Design features

There are also instances where the tailoring feature in the primary task support category was used in conjunction with features from the dialogue support category such as praise, rewards, suggestion and reminders. The tailored feedback provided by the FATaintPHAT intervention aimed at Dutch adolescents for obesity prevention, for example, combined the provision of information targeted at their age range while encouraging them to discuss that information with their family and peers (75). Another intervention used tailored interactive text encouragements to increase the aerobic fitness of Danish adolescents (58), while a third provided tailored recommendations to manage obesity (76). Tailored reinforcement messages and personalised feedback were also provided to participants in an Internet-based weight loss program (77). Tailored messages were also provided to participants according to the self-monitoring data in an SMS maintenance treatment program for obese children (48).

These results represent how PSD features could be applied in computer-mediated physical activity interventions. Twenty of the 38 articles reported clinical trial results. 
Theoretical perspectives, the behaviour change techniques applied, and the results of these studies, will be presented in the following sections.

\subsection{Theoretical perspectives and the studies}

The theory of Stage of Change (the Transtheoretical model) was applied in six studies (41, 57, 64, 78-80), Social Cognitive theory was used in eight $(43,44,72,74,81-84)$, and the theory of Planned Behaviour was applied in four $(62,66,78,79)$. Other behaviourchange interventions were also used, although different theories were applied, and this information is presented in Table 4.

Insert Table 4 here.

\subsubsection{Study type variations}

The majority of studies $(41,43,44,57,64,72,73,81-85)$ focused on the outcome comparison with or without a specific behaviour change intervention. Some studies, however, were conducted using the same behaviour change technique but utilising different media, such as printed media compared to computerised media $(45,74)$, or faceto-face interactions versus a computer-based intervention (51). The intervention periods varied widely with a minimum of 8 weeks to a maximum period of up to 2 years. The characteristics of these studies, and their outcomes, are presented in Table 5.

Insert Table 5 here.

\subsection{Effectiveness}


Importance of stage of change

When attempting to persuade individuals to change their lifestyle and modify their behavior, not all the interventions described in the reviewed papers had significant outcomes. For example, the intervention conducted by Hansen et al. (2012) indicated that there were no significant differences in physical activity in the controlled group and the intervention group of physically inactive participants because the participants were not motivated to change. The intervention was conducted for 6 months with 12,287 physically inactive participants from 11 Municipalities in Denmark. The intervention was based on the theories of Planned Behaviour and Stage of Change. Although the intervention included tailored advice, normative feedback, a training program, a forum and general support, there was no significant difference between the control and intervention groups (79). Less than 7 per cent of participants in the study frequently visited the program's website, which demonstrated that participant's readiness to change plays an important part in changing health behaviour with regard to increasing physical activity. This was paralleled by the research of Antypas and Wangberg (2014) who found that the effectiveness of a tailored intervention is based on the patient's stage of change. Both the control group ( $n=38)$ and the intervention group $(n=29)$ in their study could access basic web information related to the desired lifestyle modification, while the intervention group was provided with tailored feedback based on their answers to a questionnaire, such as reminders, visualized feedback, goal-setting, praise and encouragement of their activities. Only 19 participants remained to the end of the 3 month study period (57). 
In contrast, a 3 month study conducted by Mutsuddi and Connelly $(n=28)$, indicated that personal text messages customised according to the stage of change had resulted in the successful promotion of healthy physical activity. It was noted that the intervention had progressed the stage of change from "contemplation" to "action"(80).

Similarly, a one month follow up study conducted by Ammann et al. (2013) in Australia indicated that tailored messages from a dedicated website had a positive impact on the intervention they had designed (39). Both the theory of Stage of Change and the theory of Planned Behaviour were applied in the study. Personalised advice on physical activity was provided to participants, based on a psychosocial and physical activity questionnaire, and their answers were used to inform the feedback, suggestions and tailored messages they subsequently received. The study was based on self-reported physical activity improvements via a survey and, although a positive impact from the tailored intervention was noted, there were no significant differences among the participants who ranged in ages from 19 to 89 (39). Spittaels et al. (2007) reported in their study that there was a greater increase in the physical activity of participants in first four stages of TTM (Transtheoretical model) (41).

In a follow up study of Hong Kong Chinese school children, it was found that there were significant increases in their stage of motivational readiness in self-reported physical activity in the intervention group, eight weeks after the intervention (64). The intervention group $(n=38)$ received tailored resources and self-monitoring resources, according to their stage of change, while the control group $(n=40)$ received no intervention. (64). 
High attrition was reported in studies based on the patients' stage of change, except for the one conducted by Mutsuddi and Connelly (2014) (86) with 18 to 24 year old college students in which participants were compensated up to $\$ 100$ for their involvement (86) . Ammann et al. (2013) reported 395 out of 803 participants did not return after 1 week of study, although positive outcomes were seen in those who continued with the intervention (39).

\section{Positive outcomes}

A lifestyle behavior change program designed by Steinberg et al. (2013) resulted in participants losing an average of $1.27 \mathrm{~kg}$ in the intervention group, while the controlled arm had gained $1.14 \mathrm{~kg}$, when a follow up was conducted 6 months after the intervention (85). Participants in the intervention group $(n=26)$ received behaviour change goals based on their performance and were sent tailored messages, feedback, self-monitoring and action planning information. Videos consisting of suggestions and skill training were also sent regularly to the participants. The control group $(n=24)$ received a group education session at baseline and after six months. They were also provided with an educational video at 3 months (85).

The study conducted by Rothert et al. (2006) of a 6 week intervention program included a comparison of the outcomes of standard online information-only activity and tailored activity. A tailored expert system provided relevant information to participants according to their psychosocial profile, family history, and tailored action plan. A supportive buddy program, emails, and suggestions were also provided. The information-only program only provided general information about lifestyle modification (73). Follow up results on 
the comparative study indicated that the tailored expert system had a significant effect on participants at the 3 month and 6 month post-intervention points (73).

Reid et al. (2012) (51) also reported that the intervention group in their study that received internet coaching significantly increased their physical activity. The intervention group $(n=115)$ logged their activity daily, received motivational feedback, watched online tutorials and followed a physical activity plan. The control group $(n=108)$ received physical activity guidance from the doctor and an education booklet (51).

An online tailored program for adolescent school students demonstrated that an online behaviour change program is beneficial as it can anonymously provide the intervention to targeted individuals, which prevents stigmatisation (49). The program included providing knowledge, tracking activity, giving feedback according to the student's input, goalsetting by participants and providing encouragement (49). This was a non-randomised study but positive outcomes for physical activity were evident in the weight management intervention group.

Sixty eight percent of men and 63 per cent of women reported being motivated in the "Project Web Health" project, a web-based health promotion intervention program (42). In this program, the intervention group received 10 weeks of online lessons about lifestyle modification. The lessons were supplemented by goal-setting, personalised selfassessment, suggestions and forum discussions (42). Similarly, 77.8 per cent of participants in the intervention group were satisfied with the SMART study (87) in which there were statistically significant differences in weight loss in a 6 month period 
$(72,87)$. The SMART study was almost unique in implementing all four categories of the PSD features identified by Oinas-Kukkonen and Harjumaa (2009) .

A study conducted by King et al. (2013) noted that there were significant differences compared to the control group in a 4 month period. Applying Social Cognitive theory, the study utilized the behaviour change perspectives of goal setting, self-monitoring and social support. The health promotion intervention provided a virtual advisor to fulfil the social role (44).

\section{No significant differences}

In some studies, however, there were no significant differences between the control group and the intervention group (79). Hansen et al, (2012) (79) reported that some participants did not $\log$ in to the website and, despite being in the intervention group, they did not participate in the intervention. Studies conducted by Patrick et al., 2011 (83) indicated that there was a significant increase in physical activity but not a significant difference in weight loss in their control group.

Although the effectiveness of studies has been reported, the potential for study bias needs to be taken into consideration. Attrition bias can be seen in some of the studies $(51,83)$ as the analysis undertaken is only based on those who persisted. Participant numbers were very low in some studies $(44,57,62)$ and a confidence interval for the intervention could not be conducted. In some studies assessor blinding had not been undertaken (79) and the authors contended that because participants had submitted their results online, 
blinding was not necessary. Selection bias can also be seen in some studies (41) as participants were voluntarily involved in the physical activity intervention study.

Despite the culling process, some of the reviewed articles - which had indicated that an intervention had been conducted - were found to be discussions about a system that was still in the proposed stage of intervention (40) or the design and implementation stage (88) or the study details were presented but not the outcome $(46,65)$.

\section{Discussion}

Some features of persuasive systems have appeared frequently in previous research on computer-mediated lifestyle modification interventions. Tailoring, for example, was one of the most common features utilised (33 out of 38). This took varying forms such as: tailoring according to user groups and introducing activities; providing tailored feedback to users; and tailored interventions after participating in social networking activities. Tailoring also often appeared in conjunction with the dialogue support features as it can enhance the personalised experience of users. It should be noted, however, that there can be some discrepancies between the use of the terms "tailoring" and "personalisation" in the reviewed articles, and the definition of personalisation made by Oinas-Kukkonen and Harjumaa $(19,88)$. They differentiated between tailoring and personalisation by defining tailoring as being at the level of the user group while personalisation is at the level of the individual experience or whether the individual could change the system's user interface, 
the timing of message delivery, and other features of the system. The differentiation made by Oinas-Kukkonen and Harjumaa (2009) between these two features demonstrates that there is a fine line between tailoring and personalisation as system features, and this needs further exploration. Additionally, personalisation can be implemented by including implicit profiling which will involve identifying users' habits, activities and features of their social interactions. This type of profiling could, however, present some dilemmas regarding privacy and ethical responsibilities. As indicated by Oinas-Kukkonen and Harjumaa (2008) a persuasive system should be unobtrusive and provide information at an appropriate time (4).

A key finding made by this review is that, in most cases, the lifestyle modification applications and technologies were driven by technological opportunities and analysing consumer needs rather than any identified set of persuasive features. This is not surprising, however, as those involved in the development of a behaviour change support system may choose not to incorporate all the persuasive features identified $(18,88)$.

In fact, some of the articles describing behaviour change support systems did not use the term 'persuasive technology' but stated that the system had been designed to modify the current behaviour of users. The authors of one article (Alley et al., 2014) claimed that "no [previous] web-based physical activity interventions have provided both computertailored advice and online coaching simultaneously". As a result of their findings the "My Activity Coach" system they had designed (40) provided persuasive system features in all four of the categories identified by Oinas-Kukkonen and Harjumaa (2009) (19). Behaviour change support systems would be more effective if they provide effective communication to specific age groups, as this is likely to result in better healthcare 
outcomes and empower participants. This was demonstrated in the reviewed articles which described systems facilitating effective health behaviour change in groups of teens, adolescents, school aged children (64), college students (42), adults and older individuals (39), showing that age does not have to be a barrier when providing computer-mediated physical activity interventions and promoting healthy lifestyles.

Nevertheless, high attrition in intervention programs was noted in some of the reviewed articles. Health behaviour change studies indicated that tactics such as contract monitoring and providing rewards for adherence were used in behaviour modification programs (89). Although 63 per cent of the reviewed articles indicated that computer tailored monitoring was provided, giving rewards for adherence was barely mentioned ( 2 out of the 38 articles reviewed). In contrast, the praise feature was present in 45 per cent of the reviewed papers. Using praise and rewards as features of a persuasive system may have reduced this attrition and improved the level of behaviour modification. Adherence to a physical activity intervention has been explored in exergaming activities and these options will need to be studied further regarding physical activity behaviour change (90). Health behavioural change studies in psychology and healthcare indicate that patients' behavioural change can be divided into five stages, according to the Transtheoretical Model (91). In this model Prochaska et al. (2008) indicate that the maintenance stage is the most difficult to sustain. Current literature, however, (48) indicates that providing tailored messages to users would optimise the maintenance stage. This implies that providing tailored messages to engage users who have reached this stage would be beneficial in helping them to maintain the achieved health behavioural change. In contrast, results from Spittaels and de Bourdeaudhuij (2006) (92) indicated that there 
were notable changes in outcome in the earlier stages, compared to the maintenance stage. Persuasive Systems Design features (19) presented in these systems are similar, however, to the de Niet et al. (2012) study which was only focused on participants in the maintenance stage (46). Antypas \& Wangberg (2014) also found that patients' stage of change plays an important part in the effectiveness of the intervention (53).

Behavioural change would also be dependent on the values of the audience, their cultural norms and living patterns and these aspects need to be taken into consideration when designing a persuasive system (88). In the PSD model (Oinas-Kukkonen \& Harjumaa, 2009), these are addressed in the Persuasion Context analysis. Consequently, developers of health behavioural change support systems need to have a comprehensive understanding of the problems that can be inherent in the context of behaviour change.

For example, the problem of participants of an intervention not regularly visiting the dedicated website (79) could be addressed by mobile technology such as a smart phone running a health app, as the proliferation of smart devices has made this more feasible in recent years (18). As older mobile technologies are supplanted by smart phones, and more applications are designed to provide lifestyle interventions, it is possible to envisage that further enhancements to communication, interaction, self-monitoring etc., will be possible. (93).

The importance of recognising a person's stage of change was also strengthened by one of the studies as the intervention participants were in different stages yet demonstrated significant increases in their physical activity (79). Behaviour change techniques such as goal-setting, action planning, self-monitoring and social support were utilised in the study. This indicated that designers and developers need to consider people's stage of 
change and ensure their materials are tailored accordingly, to suit the needs of different cohorts.

Systems providing personal experiences of attainment to users through step-wise achievable goal-setting were identified in the papers on computer-mediated behaviour change support for physical activity. Users of the system described by Spittaels et al. (2007) can select action plans that were provided to them (41) while in the "COMPASS" study users can simply touch the screen to interact and select their desired plan (44). These features assist autonomy by providing support for participants' behavioural change. Additionally, Winett et al. (2007) enabled goal contracting by allowing users to select from a list of goal and action options (43). Therefore, features in the primary task support category such as tailoring, reduction and tunnelling have enabled behavioural change with regard to increasing physical activity. A tailored program for high school students (49) was designed with consideration given to the psychological needs of adolescents by maintaining their anonymity and, thus, preventing stigmatisation.

Goal-setting and self-monitoring have been identified as important aspects of exercise adherence behaviour (94) and these are supported by features in the primary task support category and this is reinforced by the results of this review.

Not only can individual features of the PSD (19) assist behaviour change, but, taken together, categories of features can also contribute to positive outcomes. The dialogue support category facets, in conjunction with those in the primary task support category, have assisted in improving the behaviour change perspectives of users in regard to undertaking physical activity. By providing tailored reinforcement messages, suggesting useful and realistic goals, providing a virtual trophy and rewards, and sending reminders 
according to their action plans, persuasive technology assisted in reinforcing, encouraging physical activity changes, and adherence to a routine.

Social facilitation, social comparison, social learning and cooperation were identified in the reviewed articles as providing effective behavioural modification approaches to increasing physical activity.

Results from the reviews demonstrated that applying persuasive technology could assist in increasing physical activity and enhancing health behavioural change attitudes. The effectiveness of interventions has been reported in several studies, as presented in Table 3. Intervention groups demonstrated increases in physical activity in most of the studies $(62,64,74,82,86)$. This shows that encouraging physical activity behaviour change via a persuasive system is comparable to behaviour change support provided in person. This review focused on the Persuasive System Design features of computer mediated physical activity changes, and the effectiveness of those interventions. Previous systemic literature reviews either focused on the effectiveness of an intervention (95), without considering the system design features, or only concentrated on the design perspectives (96) for physical activity intervention.

\section{Limitations}

This literature review was conducted to determine the current state of health promotion and intervention activities involving physical activity that used persuasive technology. The features discussed were extracted from academic articles. The limitation of the study is that features present in the actual system were not categorised or discussed in the reviewed articles. This review used the Web of Science, PubMed, and PsychInfo 
databases as these collect health sciences articles. Despite Web of Science being one which covers a broad collection of publications, it is possible that relevant articles were missed in the review. Initial search on Cochrane library only returned 2 protocols and 1 review and they were also a duplicate with the search result from other databases so Cochrane library was not included. This study focused on physical activity interventions via a computer, the web or using mobile phones, so studies using smart devices such as RFID, Nintendo Wii, XBox or other gaming applications were not included. Additionally, as the focus of the study was the identification of commonly utilised persuasive system features in computer-mediated physical activities, the articles reviewed were not only from clinical trials but also from pilot studies and studies of the design and implementation of computerised or online physical activity interventions. Although there are twenty studies containing intervention results, some studies have a very smaller sample size $(n=20)$ and the type of study varies considerably. Consequently, metaanalysis was not conducted.

\section{Conclusion}

This study systematically reviewed the literature on computer-mediated lifestyle modification, as it pertains to encouraging users to increase their physical activity, using the Oinas-Kukkonen and Harjumaa (2009) identified features of Persuasive Systems Design (PSD) (34). This review demonstrated that those features are relevant to physical 
activity intervention and highlighted the importance of an information system's actual use in lifestyle modification. Motivating behaviour change for physical activity is a complex task. Context plays an important role in persuasion and the reviewed articles demonstrated that the designers had identified the appropriate strategy to motivate their target segment of participants. The Behaviour Change Techniques, the theory used and the effectiveness of the intervention discussed in the studies were also analysed in this review. The importance of stage of change in behavioural intervention is noted and system designers need to design appropriately according to the stages .

This review also noted that the application of the PSD model varies from study to study. For example, the social support category was present in only 13 out of the 38 articles reviewed. With the increasing popularity of social media and burgeoning creation and use of mobile applications, it is highly likely that the landscape will change.

Declaration of Interests: N/A

\section{References}

1. Pandita A, Sharma D, Pandita D, Pawar S, Tariq M, Kaul A. Childhood obesity: Prevention is better than cure. Diabetes, Metabolic Syndrome and Obesity: Targets and Therapy. 2016;9:83-9.

2. Hanusaik N, Contandriopoulos D, Kishchuk N, Maximova K, Paradis G, O'Loughlin JL. Chronicling changes to the chronic disease prevention landscape in Canada's public health system 2004-2010. Public Health. 2014;128(8):716-24.

3. Khalil A, Abdallah S. Harnessing social dynamics through persuasive technology to promote healthier lifestyle. Computers in Human Behavior. 2013;29(6):2674-81.

4. Oinas-Kukkonen H, Harjumaa M, editors. A systematic framework for designing and evaluating persuasive systems2008: Springer. 
5. Doupi P, Van Wijk MA, Van Wyk JT, Van Der Lei J, editors. Personalizing patient education using Internet health resources and EPR data: Pilot evaluation of the STEPPS prototype system. Proceedings - IEEE Symposium on Computer-Based Medical Systems; 2008; Jyvaskyla.

6. Win KT, Hassan N, Bonney A, Iverson D. Benefits of Online Health Education: Perception from Consumers and Health Professionals. Journal of Medical Systems. 2015;39(3):1-8.

7. Gómez Manchón M, Gómez Carrasco JA, Ramírez Fernández J, Díez Fernández T, García de Frías E. Necesidades del niño escolarizado con diabetes mellitus. Visión de padres y profesores. Anales de Pediatría. 2009;70(1):45-52.

8. Doupi P, van der Lei J. Design and implementation considerations for a personalized patient education system in burn care. International Journal of Medical Informatics. 2005;74(2-4):151-7.

9. Plougmann S, Hejlesen OK, Cavan DA. DiasNet--a diabetes advisory system for communication and education via the internet. Int J Med Inform. 2001;64(2-3):319-30.

10. Homer C, Susskind O, Alpert HR, Owusu MPM, Celestina, Schneider L, et al. An Evaluation of an Innovative Multimedia Educational Software Program for Asthma Management: Report of a Randomized, Controlled Trial. Pediatrics. 2000;106(1):210-5.

11. Hassan NM, Win KT, editors. Exploring Design Features (Web Environment) and Perceived Benefits (Incentives) of Online Patient Education (OPE) Sites for Chronic Diseases. International Conference on Emerging Trends in Computer Science \& Information Technology; 2013; Kuala Lumpur, Malaysia.

12. Fogg BJ. Persuasive technology: using computers to change what we think and do. 2003. Morgan Kaufmann; 2003.

13. Chatterjee S, Price A. Healthy Living with Persuasive Technologies: Framework, Issues, and Challenges. Journal of the American Medical Informatics Association. 2009;16(2):171-8.

14. Kaptein M, Markopoulos P, de Ruyter B, Aarts E. Personalizing persuasive technologies: Explicit and implicit personalization using persuasion profiles.

International Journal of Human-Computer Studies. 2015;77(0):38-51.

15. Daud NA, Sahari@ Ashaari N, Muda Z. An Initial Model of Persuasive Design in Web based Learning Environment. Procedia Technology. 2013;11(0):895-902.

16. Looije R, Neerincx MA, Cnossen F. Persuasive robotic assistant for health selfmanagement of older adults: Design and evaluation of social behaviors. International Journal of Human-Computer Studies. 2010;68(6):386-97.

17. Oinas-Kukkonen, Win KT, Chatterjee S, editors. Introduction to Health Behavior Change Support Systems (HBCSS) Minitrack. 2016 49th Hawaii International Conference on System Sciences (HICSS); 2016 5-8 Jan. 2016.

18. Matthews J, Win KT, Oinas-Kukkonen H, Freeman M. Persuasive Technology in Mobile Applications Promoting Physical Activity: a Systematic Review. Journal of Medical Systems. 2016;40(3):1-13.

19. Oinas-Kukkonen H, Harjumaa M. Persuasive systems design: Key issues, process model, and system features. Communications of the Association for Information Systems. 2009;24(1):28.

20. Petty RE, Cacioppo JT. Source factors and the elaboration likelihood model of persuasion. Advances in Consumer Research. 1984;11(1):668-72. 
21. Walia N, Srite M, Huddleston W. Eyeing the web interface: the influence of price, product, and personal involvement. Electronic Commerce Research. 2015.

22. Lakey B, Cohen S. Social Support Measurement and Intervention : A Guide for Health and Social Scientists. Cary, NC, USA: Oxford University Press, USA; 2000.

23. Morrison LG, Yardley L, Powell J, Michie S. What design features are used in effective e-health interventions? A review using techniques from Critical Interpretive Synthesis. Telemed J E Health. 2012;18(2):137-44.

24. Clayman ML, Boberg EW, Makoul G. The use of patient and provider perspectives to develop a patient-oriented website for women diagnosed with breast cancer. Patient Education and Counseling. 2008;72(3):429-35.

25. Ferney SL, Marshall AL. Website physical activity interventions: preferences of potential users. Health Education Research. 2006;21(4):560-6.

26. DeGuzman MA, Ross MW. Assessing the application of HIV and AIDS related education and counselling on the Internet. Patient Education and Counseling. 1999;36(3):209-28.

27. Gosselin P, Poitras P. Use of an internet "viral" marketing software platform in health promotion. Journal of Medical Internet Research. 2008;10(4):e47.

28. Rezailashkajani M, Roshandel D, Ansari S, Zali MR. A web-based patient education system and self-help group in Persian language for inflammatory bowel disease patients. International Journal of Medical Informatics. 2008;77(2):122-8.

29. Yamout SZ, Glick ZA, Lind DS, Monson RA, Glick PL. Using social media to enhance surgeon and patient education and communication. Bull Am Coll Surg. 2011;96(7):7-15.

30. Michie S, Richardson M, Johnston M, Abraham C, Francis J, Hardeman W, et al. The behavior change technique taxonomy (v1) of 93 hierarchically clustered techniques: Building an international consensus for the reporting of behavior change interventions. Annals of Behavioral Medicine. 2013;46(1):81-95.

31. Chang SJ, Choi S, Kim S-A, Song M. Intervention Strategies Based on Information-Motivation-Behavioral Skills Model for Health Behavior Change: A Systematic Review. Asian Nursing Research. 2014;8(3):172-81.

32. Halliday TM, Savla J, Marinik EL, Hedrick VE, Winett RA, Davy BM.

Resistance training is associated with spontaneous changes in aerobic physical activity but not overall diet quality in adults with prediabetes. Physiology and Behavior. 2017;177:49-56.

33. Stacey FG, James EL, Chapman K, Lubans DR. Social cognitive theory mediators of physical activity in a lifestyle program for cancer survivors and carers: Findings from the ENRICH randomized controlled trial. International Journal of Behavioral Nutrition and Physical Activity. 2016;13(1).

34. Zechner MR, Gill KJ. Predictors of Physical Activity in Persons with Mental Illness: Testing a Social Cognitive Model. Psychiatric Rehabilitation Journal. 2016;39(4):321-7.

35. Prochaska JJ, Spring B, Nigg CR. Multiple health behavior change research: An introduction and overview. Preventive Medicine. 2008;46(3):181-8.

36. Nyman SR, Adamczewska N, Howlett N. Systematic review of behaviour change techniques to promote participation in physical activity among people with dementia. British Journal of Health Psychology. 2018;23(1):148-70. 
37. Lehto T, Oinas-Kukkonen H. Persuasive features in six weight loss websites: A qualitative evaluation. Lecture Notes in Computer Science (including subseries Lecture Notes in Artificial Intelligence and Lecture Notes in Bioinformatics)2010. p. 162-73.

38. Lehto T, Oinas-Kukkonen H. Explaining and predicting perceived effectiveness and use continuance intention of a behaviour change support system for weight loss. Behaviour and Information Technology. 2015;34(2):176-89.

39. Ammann R, Vandelanotte C, de Vries H, Mummery W. Can a website-delivered computer-tailored physical activity intervention be acceptable, usable, and effective for older people? Health Education \& Behavior. 2013;40(2):160-70.

40. Alley S, Jennings C, Plotnikoff RC, Vandelanotte C. My Activity Coach - Using video-coaching to assist a web-based computer-tailored physical activity intervention: a randomised controlled trial protocol. Bmc Public Health. 2014;14.

41. Spittaels H, De Bourdeaudhuij I, Brug J, Vandelanotte C. Effectiveness of an online computer-tailored physical activity intervention in a real-life setting. Health Education Research. 2007;22(3):385-96.

42. Dour CA, Horacek TM, Schembre SM, Lohse B, Hoerr S, Kattelmann K, et al. Process evaluation of project webhealth: A nondieting web-based intervention for obesity prevention in college students. Journal of Nutrition Education and Behavior.

2013;45(4):288-95.

43. Winett RA, Anderson ES, Wojcik JR, Winett SG, Bowden T. Guide to health:

Nutrition and physical activity outcomes of a group-randomized trial of an internet-based intervention in churches. Annals of Behavioral Medicine. 2007;33(3):251-61.

44. King AC, Bickmore TW, Campero MI, Pruitt LA, Yin JL. Employing virtual advisors in preventive care for underserved communities: Results from the COMPASS study. Journal of Health Communication. 2013;18(12):1449-64.

45. Peels D, de Vries H, Bolman C, Golsteijn R, van Stralen M, Mudde A, et al. Differences in the use and appreciation of a web-based or printed computer-tailored physical activity intervention for people aged over 50 years. Health Education Research. 2013;28(4):715-31.

46. Reinwand D, Kuhlmann T, Wienert J, de Vries H, Lippke S. Designing a theoryand evidence-based tailored eHealth rehabilitation aftercare program in Germany and the Netherlands: study protocol. Bmc Public Health. 2013;13.

47. Win KT, editor Implementing patient accessible health information site for diabetes management. Pacific Asia Conference on Information Systems; 2010.

48. de Niet J, Timman R, Bauer S, van den Akker E, Buijks H, de Klerk C, et al. The effect of a short message service maintenance treatment on body mass index and psychological well-being in overweight and obese children: A randomized controlled trial. Pediatric Obesity. 2012;7(3):205-19.

49. Jones M, Lynch KT, Kass AE, Burrows A, Williams J, Wilfley DE, et al. Healthy weight regulation and eating disorder prevention in high school students: A universal and targeted web-based intervention. Journal of Medical Internet Research. 2014;16(2):28-39. 50. Hearn L, Miller M, Fletcher A. Online healthy lifestyle support in the perinatal period: what do women want and do they use it? Australian Journal of Primary Health. 2013;19(4):313-8.

51. Reid RD, Morrin LI, Beaton LJ, Papadakis S, Kocourek J, McDonnell L, et al. Randomized trial of an internet-based computer-tailored expert system for physical 
activity in patients with heart disease. European Journal of Preventive Cardiology. 2012;19(6):1357-64.

52. Volland D, Korak K, Kowatsch T, editors. A health information system that extends healthcare professional-patient communication. ECIS 2014 Proceedings - 22nd European Conference on Information Systems; 2014.

53. Creed C, Beale R. User interactions with an affective nutritional coach. Interacting with Computers. 2012;24(5):339-50.

54. Lustria MLA, Cortese J, Noar SM, Glueckauf RL. Computer-tailored health interventions delivered over the web: Review and analysis of key components. Patient Education and Counseling. 2009;74(2):156-73.

55. Oenema A, Brug J, Lechner L. Web-based tailored nutrition education: results of a randomized controlled trial. Health Education Research. 2001;16(6):647-60.

56. Bental DS, Cawsey A, Jones R. Patient information systems that tailor to the individual. Patient Education and Counseling. 1999;36(2):171-80.

57. Antypas K, Wangberg SC. An Internet- and mobile-based tailored intervention to enhance maintenance of physical activity after cardiac rehabilitation: Short-term results of a randomized controlled trial. Journal of Medical Internet Research. 2014;16(3):78-95. 58. Klausen SH, Mikkelsen UR, Hirth A, Wetterslev J, Kjaergaard H, Sondergaard L, et al. Design and rationale for the PREVAIL study: Effect of e-Health individually tailored encouragements to physical exercise on aerobic fitness among adolescents with congenital heart disease-a randomized clinical trial. American Heart Journal. 2012;163(4):549-56.

59. Head KJ, Noar SM, Iannarino NT, Grant Harrington N. Efficacy of text messaging-based interventions for health promotion: A meta-analysis. Social Science \& Medicine. 2013;97(0):41-8.

60. Pop-Eleches C, Thirumurthy H, Habyarimana JP, Zivin JG, Goldstein MP, de Walque D, et al. Mobile phone technologies improve adherence to antiretroviral treatment in a resource-limited setting: a randomized controlled trial of text message reminders. AIDS. 2011;25(6):825-34.

61. Greaney ML, Puleo E, Sprunck-Harrild K, Bennett GG, Cunningham MA, Gillman MW, et al. Electronic reminders for cancer prevention: Factors associated with preference for automated voice reminders or text messages. Preventive Medicine. 2012;55(2):151-4.

62. Hurling R, Catt M, De Boni M, Fairley BW, Hurst T, Murray P, et al. Using Internet and mobile phone technology to deliver an automated physical activity program: Randomized controlled trial. Journal of Medical Internet Research. 2007;9(2):1-12. 63. Kelders SM, van Gemert-Pijnen JE, Werkman A, Seydel ER. Evaluation of a web-based lifestyle coach designed to maintain a healthy bodyweight. Journal of Telemedicine and Telecare. 2010;16(1):3-7.

64. Lau EY, Lau PWC, Chung PK, Ransdell LB, Archer E. Evaluation of an InternetShort Message Service-Based Intervention for Promoting Physical Activity in Hong Kong Chinese Adolescent School Children: A Pilot Study. Cyberpsychology Behavior and Social Networking. 2012;15(8):425-34.

65. Mitchell BL, Lewis NR, Smith AE, Rowlands AV, Parfitt G, Dollman J. Rural Environments and Community Health (REACH): a randomised controlled trial protocol for an online walking intervention in rural adults. Bmc Public Health. 2014;14. 
66. Vandelanotte C, Caperchione CM, Ellison M, George ES, Maeder A, Kolt GS, et al. What kinds of website and mobile phone-delivered physical activity and nutrition interventions do middle-aged men want? Journal of Health Communication. 2013;18(9):1070-83.

67. Mitchell JA, Fun J, McCray AT. Design of Genetics Home Reference: a new NLM consumer health resource. Journal of the American Medical Informatics Association. 2004;11(6):439-47.

68. Abbatangelo-Gray J, Byrd-Bredbenner C, Austin SB. Health and Nutrient Content Claims in Food Advertisements on Hispanic and Mainstream Prime-time Television. Journal of Nutrition Education and Behavior.40(6):348-54.

69. Boyer C, Selby M, Scherrer JR, Appel RD. The Health On the Net Code of Conduct for medical and health Websites. Computers in Biology and Medicine. 1998;28(5):603-10.

70. Bennett JA, Winters-Stone K. Motivating older adults to exercise: what works? Age and Ageing. 2011;40(2):148-9.

71. Ajzen I, Fishbein M. Understanding attitudes and predicting social behaviour. 1980.

72. Patrick K, Marshall SJ, Davila EP, Kolodziejczyk JK, Fowler JH, Calfas KJ, et al. Design and implementation of a randomized controlled social and mobile weight loss trial for young adults (project SMART). Contemporary Clinical Trials. 2014;37(1):10-8. 73. Rothert K, Strecher VJ, Doyle LA, Caplan WM, Joyce JS, Jimison HB, et al. Web-based Weight Management Programs in an Integrated Health Care Setting: A Randomized, Controlled Trial. Obesity. 2006;14(2):266-72.

74. Duncan M, Vandelanotte C, Kolt GS, Rosenkranz RR, Caperchione CM, George ES, et al. Effectiveness of a web-and mobile phone-based intervention to promote physical activity and healthy eating in middle-aged males: randomized controlled trial of the ManUp study. Journal of medical Internet research. 2014;16(6).

75. Ezendam N, Noordegraaf V, Kroeze W, Brug J, Oenema A. Process evaluation of FATaintPHAT, a computer-tailored intervention to prevent excessive weight gain among Dutch adolescents. Health Promot Internation. 2013;28(1):26-35.

76. Kim H-Y, Park H-A, Min YH, Jeon E. Development of an obesity management ontology based on the nursing process for the mobile-device domain. Journal of Medical Internet Research. 2013;15(6):56-66.

77. Funk KL, Stevens VJ, Bauck A, Brantley PJ, Hornbrook M, Jerome GJ, et al. Development and implementation of a tailored self-assessment tool in an internet-based weight loss maintenance program. Clinical Practice and Epidemiology in Mental Health. 2011;7.

78. De Cocker K, Spittaels H, Cardon G, De Bourdeaudhuij I, Vandelanotte C. Webbased, computer-tailored, pedometer-based physical activity advice: Development, dissemination through general practice, acceptability, and preliminary efficacy in a randomized controlled trial. Journal of Medical Internet Research. 2012;14(2):115-27. 79. Hansen AW, Gronbaek M, Helge JW, Severin M, Curtis T, Tolstrup JS. Effect of a web-based intervention to promote physical activity and improve health among physically inactive adults: A population-based randomized controlled trial. Journal of Medical Internet Research. 2012;14(5):116-29. 
80. Mutsuddi AU. The persuasive power of text messages for behavior change: Encouraging young adults to increase physical activity. Dissertation Abstracts International: Section B: The Sciences and Engineering. 2012;73(4-B):2311. 81. Migneault JP, Dedier JJ, Wright JA, Heeren T, Campbell MK, Morisky DE, et al. A culturally adapted telecommunication system to improve physical activity, diet quality, and medication adherence among hypertensive African-Americans: A randomized controlled trial. Annals of Behavioral Medicine. 2012;43(1):62-73.

82. Morgan PJ, Callister R, Collins CE, Plotnikoff RC, Young MD, Berry N, et al. The SHED-IT community trial: A randomized controlled trial of Internet- and paperbased weight loss programs tailored for overweight and obese men. Annals of Behavioral Medicine. 2013;45(2):139-52.

83. Patrick K, Calfas KJ, Norman GJ, Rosenberg D, Zabinski MF, Sallis JF, et al. Outcomes of a 12-month web-based intervention for overweight and obese men. Annals of Behavioral Medicine. 2011;42(3):391-401.

84. Schulz DN, Kremers SP, Vandelanotte C, van Adrichem MJ, Schneide F, Candel MJ, et al. Effects of a Web-based tailored multiple-lifestyle intervention for adults: A two-year randomized controlled trial comparing sequential and simultaneous delivery modes. Journal of Medical Internet Research. 2014;16(1):48-65.

85. Steinberg DM, Levine EL, Askew S, Foley P, Bennett GG. Daily text messaging for weight control among racial and ethnic minority women: Randomized controlled pilot study. Journal of Medical Internet Research. 2013;15(11):67-77.

86. Mutsuddi AU, Connelly K, editors. Text messages for encouraging physical activity Are they effective after the novelty effect wears off? 2012 6th International Conference on Pervasive Computing Technologies for Healthcare (PervasiveHealth) and Workshops; 2012 21-24 May 2012.

87. Godino JG, Merchant G, Norman GJ, Donohue MC, Marshall SJ, Fowler JH, et al. Using Social and Mobile Tools for Weight Loss in Overweight and Obese Young Adults (Project SMART): A 2-Year Parallel Group Randomized Controlled Trial. The lancet Diabetes \& endocrinology. 2016;4(9):747-55.

88. Camerini L, Giacobazzi M, Boneschi M, Schulz PJ, Rubinelli S. Design and implementation of a web-based Tailored Gymnasium to enhance self-management of Fibromyalgia. User Modeling and User-Adapted Interaction. 2011;21(4-5):485-511. 89. Cislak A, Safron M, Pratt M, Gaspar T, Luszczynska A. Family-related predictors of body weight and weight-related behaviours among children and adolescents: A systematic umbrella review. Child: Care, Health and Development. 2012;38(3):321-31. 90. Kirk A, MacMillan F, Rice M, Carmichael A. An Exploratory Study Examining the Appropriateness and Potential Benefit of the Nintendo Wii as a Physical Activity Tool in Adults Aged $\geq 55$ Years. Interacting with Computers. 2013;25(1):102-14. 91. Prochaska JO, Butterworth S, Redding CA, Burden V, Perrin N, Leo M, et al. Initial efficacy of MI, TTM tailoring and HRI's with multiple behaviors for employee health promotion. Preventive Medicine. 2008;46(3):226-31.

92. Spittaels H, de Bourdeaudhuij I. Implementation of an online tailored physical activity intervention for adults in Belgium. Health Promot Internation. 2006;21(4):311-9. 93. Jara AJ, Lopez P, Fernandez D, Zamora MA, Ubeda B, Skarmeta AF. Communication Protocol for Enabling Continuous Monitoring of Elderly People through Near Field Communications. Interacting with Computers. 2014;26(2):145-68. 
94. Pearson ES. Goal setting as a health behavior change strategy in overweight and obese adults: A systematic literature review examining intervention components. Patient Education and Counseling. 2012;87(1):32-42.

95. Broekhuizen K, Kroeze W, van Poppel MNM, Oenema A, Brug J. A Systematic Review of Randomized Controlled Trials on the Effectiveness of Computer-Tailored Physical Activity and Dietary Behavior Promotion Programs: an Update. Ann Behav Med. 2012;44:259-86.

96. Win KT, Hassan NM, Oinas-Kukkonen H, Probst Y. Online Patient Education for Chronic Disease Management: Consumer Perspectives. Journal of Medical Systems. 2016;40(4):1-13. 
Figure 1: Literature review screening process

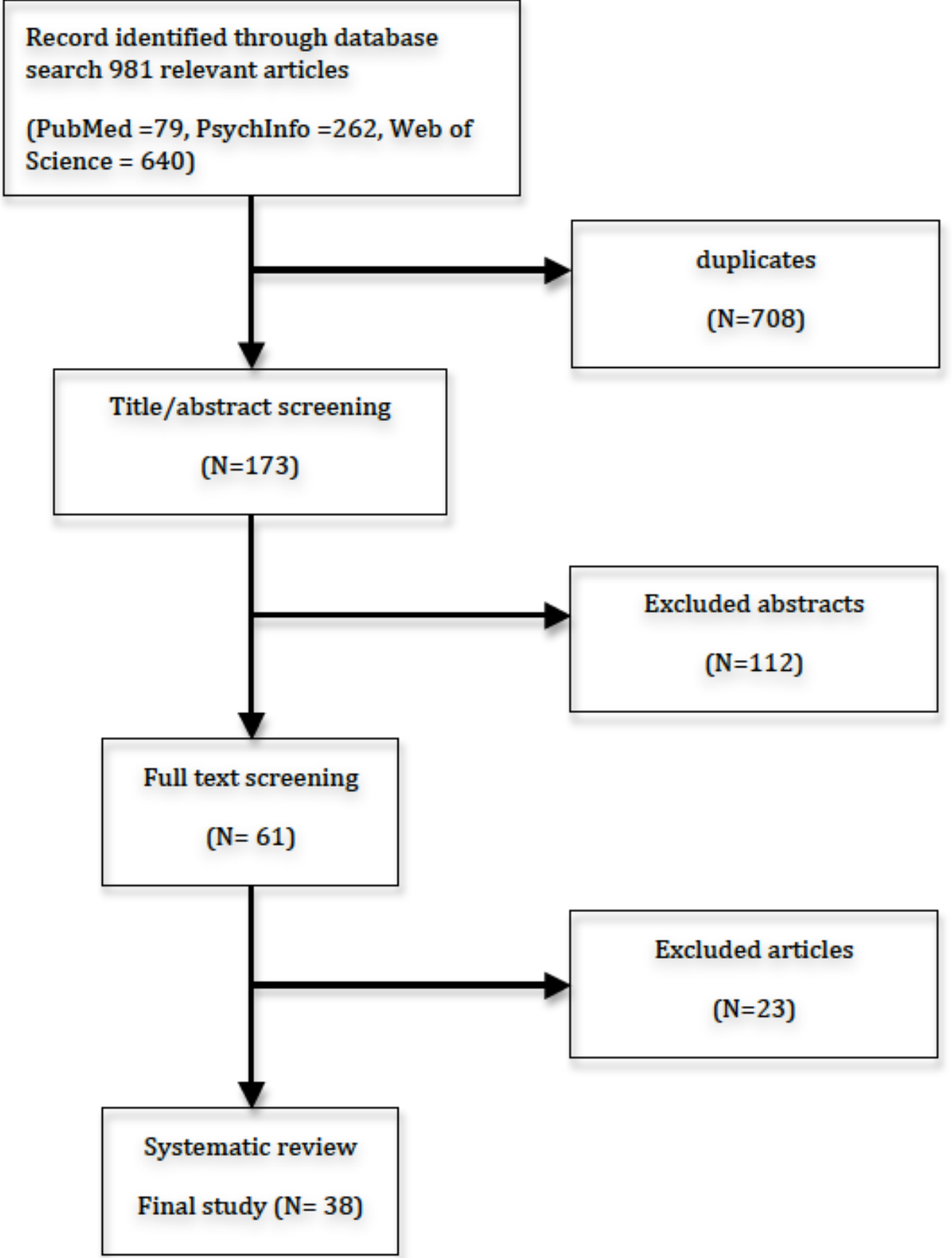


Table 1: Persuasive system design feature categories and features presented in the PSD model(Oinas-Kukkonen \& Harjumaa, 2009)

\begin{tabular}{|c|c|}
\hline \multicolumn{2}{|c|}{ Primary Task Support } \\
\hline Reduction & System should reduce effort users expend when performing target behaviour \\
\hline Tunnelling & $\begin{array}{l}\text { System should guide users in attitude change process by providing means for action that } \\
\text { brings them closer to target behaviour }\end{array}$ \\
\hline Tailoring & System should provide tailored info for user groups \\
\hline Personalization & System should offer personalized content and services for users \\
\hline Self-monitoring & System should provide means for users to track their performance or status \\
\hline Simulation & $\begin{array}{l}\text { System should provide means for observing link between cause \& effect with regard to users } \\
\text { behaviour }\end{array}$ \\
\hline Rehearsal & System should provide means for rehearsing target behaviour \\
\hline \multicolumn{2}{|l|}{ Dialogue Support } \\
\hline Praise & $\begin{array}{l}\text { System should use praise via words, images, symbols, sounds to provide user feedback based } \\
\text { on behaviours }\end{array}$ \\
\hline Rewards & $\begin{array}{l}\text { System should provide virtual rewards for users to give credit for performing target } \\
\text { behaviour }\end{array}$ \\
\hline Reminders & $\begin{array}{l}\text { System should remind users of their target behaviour or steps towards it while using the } \\
\text { system }\end{array}$ \\
\hline Suggestion & System should suggest users carry out behaviours while using the system \\
\hline Similarity & System should imitate its users in some specific way \\
\hline Liking & System should have a look \& feel that appeals to users \\
\hline Social Role & System should adopt a social role \\
\hline \multicolumn{2}{|l|}{ Credibility Support } \\
\hline Trustworthiness & System should provide info that is truthful, fair \& unbiased \\
\hline Expertise & System should provide info showing knowledge, experience \& competence \\
\hline Surface Credibility & System should have competent look \& feel \\
\hline Real-World Feel & System should provide info of the organization/actual people behind its content \& services \\
\hline Authority & System should refer to people in the role of authority \\
\hline $\begin{array}{l}\text { Third-Party } \\
\text { Endorsements }\end{array}$ & System should provide endorsements from respected sources \\
\hline Verifiability & System should provide means to verify accuracy of site content via outside sources \\
\hline \multicolumn{2}{|l|}{ Social Support } \\
\hline Social Learning & $\begin{array}{l}\text { System should provide means to observe others performing their target behaviours to see } \\
\text { outcome of their behaviour }\end{array}$ \\
\hline Social Comparison & System should provide means for comparing performance with the performance of others \\
\hline $\begin{array}{l}\text { Normative } \\
\text { Influence }\end{array}$ & $\begin{array}{l}\text { System should provide means for gathering people who have same goal \& make them feel } \\
\text { norms }\end{array}$ \\
\hline Social Facilitation & System should provide means for discerning others who are performing the behaviour \\
\hline Cooperation & System should provide means for co-operation \\
\hline Competition & System should provide means for competing with others \\
\hline Recognition & System should provide public recognition for users who perform their target behaviour \\
\hline
\end{tabular}


Table 2: Mapping of persuasive features mentioned and discussed in the reviewed papers

\begin{tabular}{|c|c|c|c|c|c|c|c|c|c|c|c|c|c|c|c|c|c|c|c|c|c|c|c|c|c|c|c|c|c|}
\hline \multicolumn{28}{|c|}{ Principles } & & \multirow{3}{*}{ 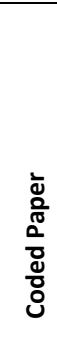 } \\
\hline 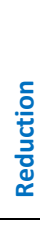 & 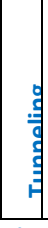 & 章 & 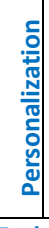 & 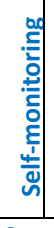 & | & 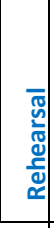 & 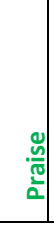 & \begin{tabular}{|l|} 
\\
0 \\
0 \\
$\vdots$ \\
$\vdots$ \\
0 \\
0 \\
\end{tabular} & 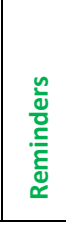 & 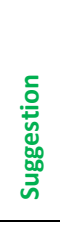 & 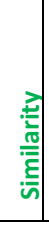 & 点 & 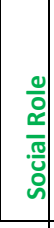 & 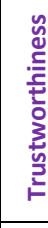 & 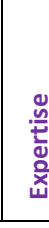 & 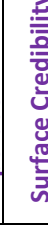 & 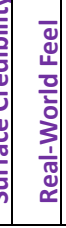 & 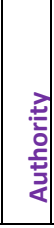 & 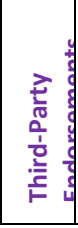 & 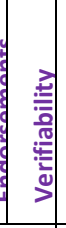 & 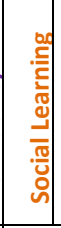 & 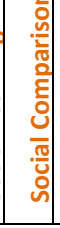 & 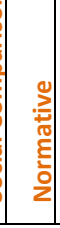 & 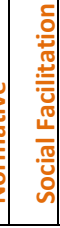 & 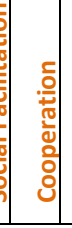 & 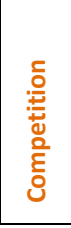 & 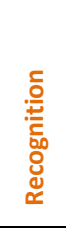 & $\begin{array}{l}\overline{\widetilde{J}} \\
\stackrel{0}{\circ}\end{array}$ & \\
\hline \multicolumn{7}{|c|}{ Primary Task Support } & \multicolumn{7}{|c|}{ Dialogue Support } & \multicolumn{7}{|c|}{ System Credibility Support } & \multicolumn{7}{|c|}{ Social Support } & & \\
\hline & $\bar{\checkmark}$ & \begin{tabular}{|l|}
$\checkmark$ \\
\end{tabular} & & & & & \begin{tabular}{|l|}
$\checkmark$ \\
\end{tabular} & & 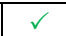 & & & & & $\checkmark$ & & & & 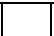 & & & & \begin{tabular}{|l|} 
\\
\end{tabular} & & & & & & 6 & A1 \\
\hline$\sqrt{4}$ & $\checkmark$ & \begin{tabular}{|l|}
$\checkmark$ \\
\end{tabular} & & & & & & & & & & & & $\checkmark$ & $\checkmark$ & & & $\checkmark$ & $\checkmark$ & $\checkmark$ & & & & & & & & 8 & A2 \\
\hline & & $\checkmark$ & & $\checkmark$ & & & $\checkmark$ & & $\checkmark$ & & & & & $\checkmark$ & $\checkmark$ & & & $\checkmark$ & $\checkmark$ & $\checkmark$ & & & & $\checkmark$ & & & & 10 & A3 \\
\hline$\sqrt{2}$ & $\checkmark$ & $\checkmark$ & & & & $\checkmark$ & & & $\checkmark$ & $\checkmark$ & & & & $\checkmark$ & $\checkmark$ & & & & & & & & & & & & & 8 & A4 \\
\hline & & \begin{tabular}{|l|}
$\checkmark$ \\
\end{tabular} & & $\checkmark$ & & & \begin{tabular}{|l|}
$\checkmark$ \\
\end{tabular} & & $\checkmark$ & $\bar{\checkmark}$ & & & & $\begin{array}{l} \\
\checkmark\end{array}$ & $\checkmark$ & & & $\checkmark$ & $\bar{\checkmark}$ & $\checkmark$ & & & & & & & & 10 & A5 \\
\hline & $\checkmark$ & \begin{tabular}{|l|} 
\\
\end{tabular} & & $\checkmark$ & 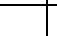 & & \begin{tabular}{|l|} 
\\
\end{tabular} & & $\checkmark$ & $\checkmark$ & & & & $\checkmark$ & $\checkmark$ & & & & & & & & & & & & & 8 & A6 \\
\hline$\checkmark$ & $\checkmark$ & $\checkmark$ & & $\checkmark$ & $\checkmark$ & & & & $\checkmark$ & & & & & $\checkmark$ & $\checkmark$ & & & & & & & $\checkmark$ & $\checkmark$ & $\checkmark$ & & & & 11 & A7 \\
\hline v & & & & $\checkmark$ & & & 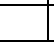 & & & & & & $\checkmark$ & $\checkmark$ & $\checkmark$ & & & & & & $\checkmark$ & $\checkmark$ & $\checkmark$ & $\checkmark$ & & & & 9 & A8 \\
\hline$\sqrt{2}$ & $\checkmark$ & $\checkmark$ & & & & & $\checkmark$ & & $\checkmark$ & $\checkmark$ & & & & $\checkmark$ & & & & & & & & $\checkmark$ & & & & & & 8 & A9 \\
\hline$\checkmark$ & $\checkmark$ & $\checkmark$ & & $\checkmark$ & & & $\checkmark$ & & $\checkmark$ & & & & & $\checkmark$ & & & & & & & & 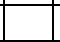 & 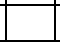 & & & & & 7 & A10 \\
\hline$\checkmark$ & $\checkmark$ & $\checkmark$ & & & & & & & & $\checkmark$ & & & $\checkmark$ & $\checkmark$ & $\checkmark$ & & & & & & $\checkmark$ & $\checkmark$ & $\checkmark$ & & & & & 10 & A11 \\
\hline & $\checkmark$ & $\checkmark$ & & 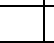 & & & & & $\checkmark$ & & & & & & $\checkmark$ & & & & & $\checkmark$ & & 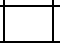 & & 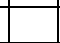 & & & & 5 & A12 \\
\hline$\checkmark$ & $\checkmark$ & \begin{tabular}{|l|}
$\checkmark$ \\
\end{tabular} & & $\checkmark$ & & & \begin{tabular}{|l|}
$r$ \\
\end{tabular} & & $\checkmark$ & $\checkmark$ & & & & 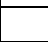 & 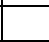 & & & & & & $\checkmark$ & \begin{tabular}{l|} 
\\
\end{tabular} & & $\checkmark$ & & & & 10 & A13 \\
\hline$\checkmark$ & $\checkmark$ & $\checkmark$ & & $\checkmark$ & & & & & & & & & & $\checkmark$ & $\checkmark$ & & & & & & & $\square$ & & & & & & 5 & A14 \\
\hline & & & & $\checkmark$ & $\checkmark$ & & & & & & & & & & & & & & & & $\checkmark$ & $\checkmark$ & $\checkmark$ & $\checkmark$ & $\checkmark$ & & & 7 & A15 \\
\hline & $\checkmark$ & \begin{tabular}{|l|} 
\\
\end{tabular} & & $\checkmark$ & & & & & $\checkmark$ & & & & & $\checkmark$ & $\checkmark$ & & & & & & & & & & & & & 6 & A16 \\
\hline & $\checkmark$ & $\checkmark$ & & $\checkmark$ & & & & & $\checkmark$ & & & & & $\checkmark$ & $\checkmark$ & & & & & & & & & & & & & 6 & A17 \\
\hline & & \begin{tabular}{|l|}
$\checkmark$ \\
\end{tabular} & & & $\checkmark$ & & & & $\checkmark$ & & $\checkmark$ & & $\checkmark$ & $\checkmark$ & $\checkmark$ & & & & & & & & & & & & & 7 & A18 \\
\hline & & \begin{tabular}{|l|} 
\\
\end{tabular} & & $\checkmark$ & & & & & $\checkmark$ & $\checkmark$ & & & & $\checkmark$ & $\checkmark$ & & & & & & & 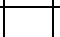 & 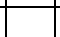 & 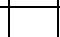 & & & & 6 & A19 \\
\hline$\checkmark$ & $\checkmark$ & \begin{tabular}{|l|}
$\checkmark$ \\
\end{tabular} & & & & & & & $\checkmark$ & $\checkmark$ & 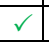 & & \begin{tabular}{|l|}
$r$ \\
\end{tabular} & $\checkmark$ & $\checkmark$ & & & & & & 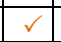 & \begin{tabular}{l|} 
\\
\end{tabular} & $\checkmark$ & $\checkmark$ & & & & 13 & A20 \\
\hline & & $\checkmark$ & & & & & & & $\checkmark$ & $\checkmark$ & $\checkmark$ & & & $\checkmark$ & $\checkmark$ & & & & & & & & & & & & & 6 & A21 \\
\hline$\sqrt{1}$ & & \begin{tabular}{|l|}
$\checkmark$ \\
\end{tabular} & & $\checkmark$ & & & & & & & & & & $\checkmark$ & $\checkmark$ & & & & & & $\checkmark$ & \begin{tabular}{l|} 
\\
\end{tabular} & $\bar{\checkmark}$ & $\checkmark$ & & & & 9 & A22 \\
\hline & & $\checkmark$ & $\checkmark$ & $\checkmark$ & & & & & & & & & & $\checkmark$ & $\checkmark$ & & & & & & & & & & & & & 5 & A23 \\
\hline & & \begin{tabular}{|l|}
$\checkmark$ \\
\end{tabular} & & $\checkmark$ & & & \begin{tabular}{|l|}
$\checkmark$ \\
\end{tabular} & & $\checkmark$ & $\bar{\checkmark}$ & & & \begin{tabular}{|l|}
$\checkmark$ \\
\end{tabular} & & 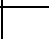 & & & & & & & \begin{tabular}{l|} 
\\
\end{tabular} & $\bar{\checkmark}$ & $\checkmark$ & $\checkmark$ & & & 10 & A24 \\
\hline$\checkmark$ & $\checkmark$ & $\checkmark$ & $\checkmark$ & $\checkmark$ & $\checkmark$ & & & & $\checkmark$ & $\checkmark$ & & & & $\checkmark$ & $\checkmark$ & & & & & & & & & & & & & 10 & A25 \\
\hline & $\checkmark$ & $\checkmark$ & & $\checkmark$ & & & & $\checkmark$ & $\checkmark$ & $\checkmark$ & & & $\checkmark$ & $\checkmark$ & $\checkmark$ & & & $\checkmark$ & $\checkmark$ & $\checkmark$ & $\checkmark$ & $\checkmark$ & $\checkmark$ & $\checkmark$ & $\checkmark$ & $\checkmark$ & $\checkmark$ & 19 & A26 \\
\hline$\checkmark$ & $\checkmark$ & \begin{tabular}{|l|} 
\\
\end{tabular} & & $\checkmark$ & $\checkmark$ & & \begin{tabular}{|l|}
$\checkmark$ \\
\end{tabular} & & $\checkmark$ & $\bar{\checkmark}$ & & & & $\checkmark$ & $\checkmark$ & & & $\checkmark$ & $\checkmark$ & $\checkmark$ & & & & & & & & 13 & A27 \\
\hline$\checkmark$ & $\gamma$ & $\checkmark$ & & 9 & & & $\checkmark$ & & $\checkmark$ & $\checkmark$ & & & & $\checkmark$ & $\checkmark$ & & & & & & & & & & & & & 9 & A28 \\
\hline$\checkmark$ & $\checkmark$ & $\checkmark$ & & $\checkmark$ & . & & $\checkmark$ & & $\checkmark$ & $\checkmark$ & & & \begin{tabular}{|l|}
$\checkmark$ \\
\end{tabular} & & & & & $\checkmark$ & & & $\checkmark$ & $\checkmark$ & $\checkmark$ & $\checkmark$ & $\checkmark$ & & & 14 & A29 \\
\hline$\sqrt{1}$ & $\checkmark$ & \begin{tabular}{|l|}
$\checkmark$ \\
\end{tabular} & \begin{tabular}{|l|} 
\\
\end{tabular} & \begin{tabular}{l|l} 
\\
\end{tabular} & $\begin{array}{ll} \\
\end{array}$ & & \begin{tabular}{|l|}
$\checkmark$ \\
\end{tabular} & & $\checkmark$ & $\checkmark$ & & & & $\checkmark$ & $\checkmark$ & & & & & & & & & & & & & 11 & A30 \\
\hline$\sqrt{4}$ & $\checkmark$ & & & & & & & & $\checkmark$ & & & & & $\checkmark$ & $\checkmark$ & & & & & & & & & & & & & 5 & A31 \\
\hline$\checkmark$ & $\checkmark$ & $\begin{array}{ll}\checkmark \\
\end{array}$ & & $\begin{array}{l} \\
\end{array}$ & $\checkmark$ & & 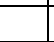 & & $\checkmark$ & $\checkmark$ & & & & $\checkmark$ & $\checkmark$ & & & & & & & & & & & & & 9 & A32 \\
\hline & $\checkmark$ & & & $\checkmark$ & $\checkmark$ & & $\begin{array}{ll} \\
\end{array}$ & & $\checkmark$ & & & & & $\checkmark$ & $\checkmark$ & & & & & & & $\checkmark$ & & & & & & 8 & A33 \\
\hline$\checkmark$ & $\checkmark$ & $\checkmark$ & & & & & $\checkmark$ & & $\checkmark$ & $\checkmark$ & & & & $\checkmark$ & $\checkmark$ & & & $\checkmark$ & & & & & & & & & & 9 & A34 \\
\hline 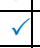 & $\checkmark$ & $\checkmark$ & & & & & $\checkmark$ & & $\checkmark$ & $\checkmark$ & & & & $\checkmark \checkmark$ & $\checkmark$ & & & & & & & & & & & & & 8 & A35 \\
\hline & & $\checkmark$ & & $\checkmark$ & $\checkmark$ & & $\checkmark$ & & $\checkmark$ & $\checkmark$ & & & & $\checkmark$ & $\checkmark$ & & & & & & & & & & & & & 8 & A36 \\
\hline$\checkmark$ & $\checkmark$ & & & & $\checkmark$ & & & & $\checkmark$ & $\checkmark$ & & & & \begin{tabular}{|l|}
$\checkmark$ \\
\end{tabular} & $\checkmark$ & & & & & & & & & & & & & 7 & A37 \\
\hline$\checkmark$ & $\checkmark$ & $\checkmark$ & & \begin{tabular}{l|} 
\\
\end{tabular} & $\checkmark$ & & $\begin{array}{ll} \\
\end{array}$ & \begin{tabular}{|l|}
$r$ \\
\end{tabular} & $\checkmark$ & & & & & $\checkmark$ & $\checkmark$ & & & & & & $\checkmark$ & $\checkmark$ & $\checkmark$ & $\checkmark$ & $\checkmark$ & & & 15 & A38 \\
\hline ণ & $\hat{\imath}$ & $m$ & $m$ & $\stackrel{\Delta}{\Delta}$ & $=$ & - & $\stackrel{\infty}{-}$ & 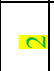 & ల్లి & ป & $m$ & 0 & $\pi$ & ले & $\bar{m}$ & 0 & 0 & $N$ & in & 0 & 9 & $\exists$ & $=$ & $\exists$ & $\forall$ & - & - & & \\
\hline
\end{tabular}




\begin{tabular}{|c|c|c|c|}
\hline & Article & Country & PSD Features Present \\
\hline A1 & $\begin{array}{l}\text { (Alley, Jennings, Plotnikoff, \& Vandelanotte, } \\
\text { 2014) }\end{array}$ & Australia & $\begin{array}{l}\text { Tunnelling, Tailoring } \\
\text { Praise, Reminders, } \\
\text { Trustworthiness, } \\
\text { Social Comparison }\end{array}$ \\
\hline $\mathrm{A} 2$ & $\begin{array}{l}\text { (Ammann, Vandelanotte, de Vries, \& } \\
\text { Mummery, 2013) }\end{array}$ & Australia & $\begin{array}{l}\text { Reduction, Tunnelling, Tailoring } \\
\text { Trustworthiness, Expertise, Authority, Third Party Endorsement, Verifiability }\end{array}$ \\
\hline A3 & (Antypas \& Wangberg, 2014) & Norway & $\begin{array}{l}\text { Tailoring, Self-Monitoring, } \\
\text { Praise, Reminders, } \\
\text { Trustworthiness, Expertise, Authority, Third Party Endorsement, Verifiability }\end{array}$ \\
\hline A4 & $\begin{array}{l}\text { (Camerini, Giacobazzi, Boneschi, Schulz, \& } \\
\text { Rubinelli, 2011) }\end{array}$ & Switzerland & $\begin{array}{l}\text { Reduction, Tunnelling, Tailoring, Rehearsal } \\
\text { Reminders, Suggestion, } \\
\text { Trustworthiness, Expertise }\end{array}$ \\
\hline A5 & $\begin{array}{l}\text { (De Cocker, Spittaels, Cardon, De } \\
\text { Bourdeaudhuij, \& Vandelanotte, 2012) }\end{array}$ & Belgium & $\begin{array}{l}\text { Tailoring, Self-Monitoring, } \\
\text { Praise, Reminders, Suggestion, } \\
\text { Trustworthiness, Expertise, Authority, Third Party Endorsement, Verifiability }\end{array}$ \\
\hline A6 & (de Niet et al., 2012) & Netherlands & $\begin{array}{l}\text { Tunnelling, Tailoring, Self-monitoring } \\
\text { Praise, Reminders, Suggestion, } \\
\text { Trustworthiness, Expertise }\end{array}$ \\
\hline A7 & (Dour et al., 2013) & USA & $\begin{array}{l}\text { Reduction, Tunnelling, Tailoring, } \\
\text { Self-Monitoring, Simulation, } \\
\text { Trustworthiness, Expertise, } \\
\text { Social Comparison, Normative Influence, Social Facilitation }\end{array}$ \\
\hline A8 & Duncan et al. & Australia & Reduction, self-monitoring, social role, trust worthiness, expertise \\
\hline A9 & $\begin{array}{l}\text { (Ezendam, Noordegraaf, Kroeze, Brug, \& } \\
\text { Oenema, 2013) }\end{array}$ & Netherlands & $\begin{array}{l}\text { Reduction, Tunnelling, Tailoring } \\
\text { Praise, Reminders, Suggestion, } \\
\text { Trustworthiness, } \\
\text { Social Comparison }\end{array}$ \\
\hline A10 & (Funk et al., 2011) & USA & $\begin{array}{l}\text { Reduction, Tunnelling, Tailoring, } \\
\text { Self-Monitoring, } \\
\text { Praise, Reminders, } \\
\text { Trustworthiness }\end{array}$ \\
\hline A11 & (Hansen et al., 2012) & Denmark & $\begin{array}{l}\text { Reduction, Tunnelling, Tailoring, } \\
\text { Suggestion, Social Role, Trustworthiness, Expertise, }\end{array}$ \\
\hline
\end{tabular}




\begin{tabular}{|c|c|c|c|}
\hline & & & Social Learning, Social Comparison, Normative Influence \\
\hline A12 & (Hearn, Miller, \& Fletcher, 2013) & Australia & $\begin{array}{l}\text { Tunnelling, Tailoring, } \\
\text { Reminders, } \\
\text { Expertise, Verifiability }\end{array}$ \\
\hline A13 & (Hurling et al., 2007) & UK & $\begin{array}{l}\text { Reduction, Tunnelling, Tailoring, } \\
\text { Self-Monitoring, } \\
\text { Praise, Reminders, Suggestion, } \\
\text { Social Learning, Social Comparison, Social Facilitation }\end{array}$ \\
\hline A14 & (Jahangiry et al., 2014) & Iran & $\begin{array}{l}\text { Reduction, Tunnelling, Tailoring, } \\
\text { Self-Monitoring, } \\
\text { Trustworthiness, Expertise }\end{array}$ \\
\hline A15 & (Jones et al., 2014) & USA & $\begin{array}{l}\text { Self-Monitoring, Simulation, } \\
\text { Social Learning, Social Comparison, Normative Influence, Social Facilitation }\end{array}$ \\
\hline A16 & $\begin{array}{l}\text { (Kelders, van Gemert-Pijnen, Werkman, \& } \\
\text { Seydel, 2010) }\end{array}$ & Netherlands & $\begin{array}{l}\text { Tunnelling, Tailoring, Self-Monitoring, } \\
\text { Reminders } \\
\text { Trustworthiness, Expertise }\end{array}$ \\
\hline A17 & (Kim, Park, Min, \& Jeon, 2013) & Korea & $\begin{array}{l}\text { Tunnelling, Tailoring, Self-Monitoring, } \\
\text { Reminders, } \\
\text { Trustworthiness, Expertise }\end{array}$ \\
\hline A18 & $\begin{array}{l}\text { (King, Bickmore, Campero, Pruitt, \& Yin, } \\
\text { 2013) }\end{array}$ & USA & $\begin{array}{l}\text { Tailoring, Simulation, } \\
\text { Reminders, Similarity, Social Role, Trustworthiness, Expertise }\end{array}$ \\
\hline A19 & (Klausen et al., 2012) & Denmark & Tailoring, Self-Monitoring, Reminders, Suggestion, Trustworthiness, Expertise \\
\hline A20 & (Lau, Lau, Chung, Ransdell, \& Archer, 2012) & Hong Kong & $\begin{array}{l}\text { Tunnelling, Tailoring, Reminders, Suggestion, Similarity, Social Role, } \\
\text { Trustworthiness, Expertise, Social Learning, Social Comparison, Normative Influence, } \\
\text { Social Facilitation }\end{array}$ \\
\hline A21 & (Migneault et al., 2012) & USA & Tailoring, Reminders, Suggestion, Similarity, Trustworthiness, Expertise \\
\hline A22 & (Mitchell et al., 2014) & Australia & $\begin{array}{l}\text { Tailoring, Self-Monitoring, Trustworthiness, Expertise, Social Learning, Social } \\
\text { Comparison, Normative Influence, Social Facilitation }\end{array}$ \\
\hline A23 & (Morgan et al., 2013) & Australia & Tailoring, Personalisation, Self-Monitoring, Trustworthiness, Expertise \\
\hline A24 & (Mutsuddi, 2012) & USA & $\begin{array}{l}\text { Tailoring, Self-Monitoring, Praise, Reminders, Suggestion, Social Role, Social } \\
\text { Comparison, Normative Influence, Social Facilitation, Cooperation }\end{array}$ \\
\hline A25 & (Patrick et al., 2011) & USA & $\begin{array}{l}\text { Tunnelling, Tailoring, Personalisation, Self-Monitoring, Simulation, Reminders, } \\
\text { Suggestion, Trustworthiness, Expertise }\end{array}$ \\
\hline A26 & ( Patrick et al., 2014) & USA & $\begin{array}{l}\text { Tunnelling, Tailoring, Self-Monitoring, Rewards, Reminders, Suggestion, Social Role, } \\
\text { Trustworthiness, Expertise, Authority, Third Party Endorsements, Verifiability, Social } \\
\text { Learning, Social Comparison, Normative Influence, Social Facilitation, Cooperation, } \\
\text { Competition, Recognition }\end{array}$ \\
\hline
\end{tabular}




\begin{tabular}{|c|c|c|c|}
\hline A27 & (Peels et al., 2013) & Netherlands & $\begin{array}{l}\text { Tunnelling, Tailoring, Self-Monitoring, Simulation, Praise, Reminders, Suggestion, } \\
\text { Trustworthiness, Expertise, Authority, Third Party Endorsements, Verifiability }\end{array}$ \\
\hline A28 & (Pollak et al., 2014) & USA & $\begin{array}{l}\text { Tunnelling, Tailoring, Self-Monitoring, Praise, Reminders, Suggestion, } \\
\text { Trustworthiness, Expertise }\end{array}$ \\
\hline A29 & (Postrach et al., 2013) & Germany & $\begin{array}{l}\text { Tunnelling, Tailoring, Self-Monitoring, Praise, Reminders, Suggestion, Social Role, } \\
\text { Authority, Social Learning, Social Comparison, Normative Influence, Social } \\
\text { Facilitation, Cooperation }\end{array}$ \\
\hline A30 & (Reid et al., 2012) & Canada and UK & $\begin{array}{l}\text { Tunnelling, Tailoring, Personalisation, Self-Monitoring, Simulation, Praise, } \\
\text { Reminders, Suggestion, Trustworthiness, Expertise }\end{array}$ \\
\hline A31 & $\begin{array}{l}\text { (Reinwand, Kuhlmann, Wienert, de Vries, \& } \\
\text { Lippke, 2013) }\end{array}$ & $\begin{array}{l}\text { Germany and } \\
\text { Netherlands }\end{array}$ & Tunnelling, Reminders, Trustworthiness, Expertise \\
\hline A32 & (Rothert et al., 2006) & US & $\begin{array}{l}\text { Tunnelling, Tailoring, Self-Monitoring, Simulation, Reminders, Suggestion, } \\
\text { Trustworthiness, Expertise }\end{array}$ \\
\hline A33 & (Schulz et al., 2014) & Netherlands & $\begin{array}{l}\text { Tunnelling, Self-Monitoring, Simulation, Praise, Reminders, Trustworthiness, } \\
\text { Expertise, Social Comparison }\end{array}$ \\
\hline A34 & (Spittaels \& de Bourdeaudhuij, 2006) & Belgium & $\begin{array}{l}\text { Tunnelling, Tailoring, Praise, Reminders, Suggestion, Trustworthiness, Expertise, } \\
\text { Authority }\end{array}$ \\
\hline A35 & $\begin{array}{l}\text { (Spittaels, De Bourdeaudhuij, Brug, \& } \\
\text { Vandelanotte, 2007) }\end{array}$ & Belgium & Tunnelling, Tailoring, Praise, Reminders, Suggestion, Trustworthiness, Expertise \\
\hline A36 & $\begin{array}{l}\text { (Steinberg, Levine, Askew, Foley, \& Bennett, } \\
\text { 2013) }\end{array}$ & USA & $\begin{array}{l}\text { Tailoring, Self-Monitoring, Simulation, Praise, Reminders, Suggestion, } \\
\text { Trustworthiness, Expertise }\end{array}$ \\
\hline A37 & $\begin{array}{l}\text { (Vandelanotte, Duncan, Plotnikoff, \& } \\
\text { Mummery, 2012) }\end{array}$ & Australia & Tunnelling, Simulation, Reminders, Suggestion, Trustworthiness, Expertise \\
\hline A38 & $\begin{array}{l}\text { (Winett, Anderson, Wojcik, Winett, \& } \\
\text { Bowden, 2007) }\end{array}$ & USA & $\begin{array}{l}\text { Tunnelling, Tailoring, Self-Monitoring, Simulation, Praise, Rewards, Reminders, } \\
\text { Trustworthiness, Expertise } \\
\text { Social learning, Social comparison, Normative influence, Social facilitation, } \\
\text { Cooperation }\end{array}$ \\
\hline
\end{tabular}

Table: 3: Persuasive features 


\begin{tabular}{|c|c|c|c|c|c|c|c|c|c|c|c|}
\hline & & Article & 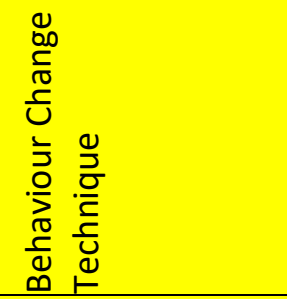 & 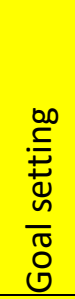 & 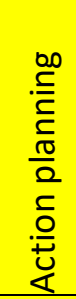 & 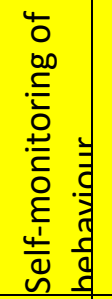 & 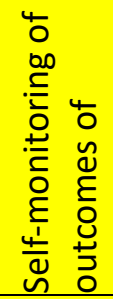 & 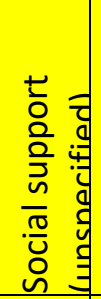 & 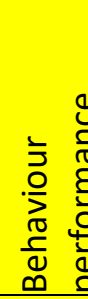 & 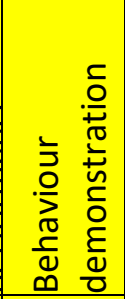 & 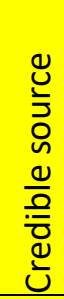 \\
\hline 1 & A3 & Antypas \& Wangberg, 2014 & TTM & $\mathrm{X}$ & & $X$ & $x$ & $x$ & & & $\mathrm{X}$ \\
\hline 2 & A5 & De Cocker et al., 2012 & TPB, TTM & & $x$ & $x$ & $x$ & $x$ & $x$ & $x$ & $x$ \\
\hline 3 & A8 & Duncan et al., 2014 & $\mathrm{SCT}$ & $x$ & $X$ & $X$ & $\mathrm{X}$ & & & & $x$ \\
\hline 4 & A10 & Funk et al., 2011 & & $X$ & $x$ & $x$ & $X$ & $x$ & & & $x$ \\
\hline 5 & A11 & Hansen et al., 2012 & TTM, TPB & $\mathrm{X}$ & $X$ & $\mathrm{X}$ & & $x$ & & & $\mathrm{X}$ \\
\hline 6 & A13 & Hurling et al., 2007 & TPB & $x$ & $X$ & $\mathrm{X}$ & $\mathrm{X}$ & & $x$ & $x$ & $x$ \\
\hline 7 & A18 & King et al., 2013 & SCT & $x$ & & $x$ & $\mathrm{X}$ & $x$ & & & $x$ \\
\hline 8 & $\mathrm{~A} 20$ & Lau et al., 2012 & TTM & $\mathrm{X}$ & & $X$ & $X$ & & & & $\mathrm{X}$ \\
\hline 9 & $\mathrm{~A} 21$ & Migneault et al., 2012 & SCT, TTM & & $x$ & $x$ & $\mathrm{X}$ & $x$ & & & $x$ \\
\hline 10 & $\mathrm{~A} 23$ & Morgan et al., 2013 & SCT & $\mathrm{X}$ & & $x$ & $\mathrm{X}$ & & & & $\mathrm{X}$ \\
\hline 11 & A24 & Mutsuddi \& Connelly, 2012 & TTM & & & $\mathrm{X}$ & $\mathrm{X}$ & $X$ & & & $\mathrm{X}$ \\
\hline 12 & A25 & Patrick et al., 2011 & SCT, SDT & & & $x$ & $x$ & & & & $\mathrm{X}$ \\
\hline 13 & A26 & Patrick et al., 2014 & SCT & $X$ & $X$ & $\mathrm{X}$ & $\mathrm{X}$ & $x$ & & & $x$ \\
\hline 14 & $\mathrm{~A} 27$ & Peels et al., 2013 & Social Modelling & & $x$ & $x$ & $x$ & & & & $x$ \\
\hline 15 & A30 & Reid et al., 2012 & & $x$ & $X$ & $x$ & $x$ & & & & $\mathrm{X}$ \\
\hline 16 & A32 & Rothert et al., 2006 & & $x$ & $x$ & $x$ & $x$ & & & & $x$ \\
\hline 17 & A33 & Schulz et al., 2014 & SCT & $x$ & $X$ & $x$ & $X$ & & & & $x$ \\
\hline 18 & A35 & Spittaels et al., 2007 & TTM & $x$ & & $x$ & $x$ & $x$ & & & $x$ \\
\hline 19 & A36 & Steinberg et al., 2013 & & $x$ & $x$ & $x$ & $x$ & & & & $x$ \\
\hline 20 & A38 & Winett et al., 2007 & SCT & $\mathrm{X}$ & $X$ & $x$ & $X$ & $x$ & & & $x$ \\
\hline
\end{tabular}

TTM = Transtheoretical model (Theory of Stage of Change), SCT = Social Cognitive Theory, TPB = Theory of Planned Behaviour,

SDT = Self Determinant Theory 
Table 4: Theories and behaviour change techniques 


\begin{tabular}{|c|c|c|c|c|c|c|c|c|c|}
\hline & & Article & Study Type & $\begin{array}{l}\text { techniques for } \\
\text { intervention } \\
\text { group }\end{array}$ & $\begin{array}{l}\text { Interventio } \\
\text { n duration, } \\
\text { frequency }\end{array}$ & $\begin{array}{l}\text { PSD Features } \\
\text { Present }\end{array}$ & Effectiveness & $\begin{array}{l}\text { Control } \\
\text { group }\end{array}$ & Method \\
\hline 1 & A3 & $\begin{array}{l}\text { (Antypas \& } \\
\text { Wangberg, } \\
\text { 2014) }\end{array}$ & $\begin{array}{l}\text { Randomise } \\
\text { d controlled } \\
\text { trial } \\
\text { ( } 2 \text { arms) } \\
\text { Adults (33- } \\
75 \text { years) } \\
\mathrm{N}=67 \\
\text { (control=38 } \\
\text {,tailored=2 } \\
\text { 9) }\end{array}$ & $\begin{array}{l}\text { Monitoring of } \\
\text { physical } \\
\text { activity, social } \\
\text { support }\end{array}$ & $\begin{array}{l}\text { Generic } \\
\text { content, } \\
\text { online forum } \\
\text { and tailored } \\
\text { intervention, } \\
\text { IPAQ } \\
\text { questionnair } \\
\text { e at } 1 \text { month } \\
\& 3 \text { months }\end{array}$ & $\begin{array}{l}\text { Tailoring, Self- } \\
\text { Monitoring, } \\
\text { Praise, } \\
\text { Reminders, } \\
\text { Trustworthiness, } \\
\text { Expertise, } \\
\text { Authority, Third } \\
\text { Party } \\
\text { Endorsement, } \\
\text { Verifiability }\end{array}$ & $\begin{array}{l}\text { Effectiveness } \\
\text { based on patients' } \\
\text { stage of change. } \\
\text { Significant level } \\
\text { of walking, } \\
\text { reason: did not } \\
\text { need help) }\end{array}$ & $\begin{array}{l}\text { Generic } \\
\text { version of } \\
\text { website and } \\
\text { online } \\
\text { forum/Tailor } \\
\text { ed } \\
\text { intervention }\end{array}$ & $\begin{array}{l}\text { Assessors blinded to } \\
\text { the group assignment } \\
\text { (high attrition rate in } \\
\text { the intervention } \\
\text { group) } \\
\text { Small sample size, } \\
\text { non-parametric test }\end{array}$ \\
\hline 2 & A5 & $\begin{array}{l}\text { (De Cocker, } \\
\text { Spittaels, } \\
\text { Cardon, De } \\
\text { Bourdeaudh } \\
\text { uij, \& } \\
\text { Vandelanott } \\
\text { e, 2012) }\end{array}$ & $\begin{array}{l}\text { Randomise } \\
\text { d controlled } \\
\text { trail }(2 \\
\text { arms }) \\
(18-65 \\
\text { years) } \\
\mathrm{N}=92 \\
\text { (control= } \\
47, \\
\text { intervention } \\
=45)\end{array}$ & $\begin{array}{l}\text { Tailored advice, } \\
\text { feedback about } \\
\text { participants' } \\
\text { intentions, } \\
\text { attitudes, self- } \\
\text { efficacy, social } \\
\text { support, } \\
\text { knowledge, } \\
\text { benefits, and } \\
\text { barriers related } \\
\text { to physical } \\
\text { activity }\end{array}$ & $\begin{array}{l}\text { Daily with } \\
\text { feedback } \\
\text { and follow } \\
\text { up at } 1 \\
\text { month for } 3 \\
\text { months }\end{array}$ & $\begin{array}{l}\text { Tailoring, Self- } \\
\text { Monitoring, } \\
\text { Praise, } \\
\text { Reminders, } \\
\text { Suggestion, } \\
\text { Trustworthiness, } \\
\text { Expertise, } \\
\text { Authority, Third } \\
\text { Party } \\
\text { Endorsement, } \\
\text { Verifiability }\end{array}$ & $\begin{array}{l}\text { No superior effect } \\
\text { compared to self- } \\
\text { reported and } \\
\text { pedometer-based } \\
\text { physical activity }\end{array}$ & $\begin{array}{l}\text { Pedometer + } \\
\text { Computer/ } \\
\text { Pedometer } \\
\text { only }\end{array}$ & $\begin{array}{l}\text { Descriptive statistics } \\
\text { Small sample } 13 \text { out } \\
\text { of } 45 \text { drop out in } \\
\text { intervention group. }\end{array}$ \\
\hline 3 & A8 & $\begin{array}{l}\text { Duncan et } \\
\text { al. }\end{array}$ & $\begin{array}{l}\text { Randomise } \\
\text { d controlled } \\
\text { trial } \\
35-54 \text { years } \\
\text { old male } \\
\mathrm{N}=301, \mathrm{IT} \\
\text { based arm = } \\
205, \text { printed } \\
\text { arm }=96\end{array}$ & $\begin{array}{l}\text { Self-monitoring, } \\
\text { goal setting, } \\
\text { social } \\
\text { interaction, } \\
\text { social support, }\end{array}$ & $\begin{array}{l}\text { Mobile } \\
\text { phone based, } \\
9 \text { Month } \\
\text { study } \\
\text { baseline, } 3 \\
\text { months and } \\
9 \text { months } \\
\text { measure, } \\
\text { walking, } \\
\text { cycling, } \\
\text { swimming, } \\
\text { running, } \\
\text { sport and } \\
\text { recreation, }\end{array}$ & $\begin{array}{l}\text { Reduction, self- } \\
\text { monitoring, } \\
\text { social role, trust } \\
\text { worthiness, } \\
\text { expertise }\end{array}$ & $\begin{array}{l}\text { Significant } \\
\text { improvement in } \\
\text { physical activity, } \\
\text { however, not } \\
\text { significant } \\
\text { difference } \\
\text { between IT and } \\
\text { printed arm }\end{array}$ & $\begin{array}{l}\text { Printed } \\
\text { based } \\
\text { intervention }\end{array}$ & $\begin{array}{l}\text { Outcome measured } \\
\text { but usage of the } \\
\text { material in the } \\
\text { controlled arm is no } \\
\text { assessed. }\end{array}$ \\
\hline
\end{tabular}




\begin{tabular}{|c|c|c|c|c|c|c|c|c|c|}
\hline & & & & & $\begin{array}{l}\text { strengthenin } \\
\mathrm{g}\end{array}$ & & & & \\
\hline 4 & A10 & $\begin{array}{l}\text { (Funk et al., } \\
\text { 2011) }\end{array}$ & $\begin{array}{l}\text { Randomize } \\
\text { d trial } \\
\text { testing } \\
\text { long-term } \\
\text { efficacy of } \\
\text { different } \\
\text { strategies (3 } \\
\text { arms) } \\
\text { Patients } \\
\text { who lost } 4 \\
\text { kg or more } \\
\text { in } 6 \text { months } \\
\text { study in } \\
\text { phase } 1 \text { are } \\
\text { continued } \\
\text { in this study } \\
\text { as phase } \\
\text { Internet } \\
\text { intervention } \\
=348 \\
\text { Total } \\
\text { participant - } \\
1032\end{array}$ & $\begin{array}{l}\text { record weight, } \\
\text { physical } \\
\text { activity, social } \\
\text { support, self- } \\
\text { monitoring, } \\
\text { reliable } \\
\text { information, } \\
\text { supportive tools } \\
\text { for change, } \\
\text { accountability, } \\
\text { tailored } \\
\text { reinforcement } \\
\text { messages, } \\
\text { tailored action } \\
\text { plan, } \\
\text { individualised } \\
\text { summary report }\end{array}$ & $\begin{array}{l}\text { Internet } \\
\text { based } \\
\text { maintenance }\end{array}$ & $\begin{array}{l}\text { Reduction, } \\
\text { Tunnelling, } \\
\text { Tailoring, } \\
\text { Self- } \\
\text { Monitoring, } \\
\text { Praise, } \\
\text { Reminders, } \\
\text { Trustworthiness }\end{array}$ & $\begin{array}{l}\text { Tool development } \\
\text { for the study was } \\
\text { described but not } \\
\text { its effectiveness }\end{array}$ & $\begin{array}{l}\text { One self- } \\
\text { directed } \\
\text { group and } \\
\text { one personal } \\
\text { contact } \\
\text { group }\end{array}$ & $\begin{array}{l}\text { Assessment is related } \\
\text { to the times that user } \\
\text { use the site }\end{array}$ \\
\hline 5 & A11 & $\begin{array}{l}\text { (Hansen et } \\
\text { al., 2012) }\end{array}$ & $\begin{array}{l}\text { Randomise } \\
\mathrm{d} \text { controlled } \\
\text { trial on } \\
\text { physical } \\
\text { activity } \\
\text { promotion } \\
\text { ( } 2 \text { arms) } \\
\text { adults ( } 18+ \\
\text { years) } \\
\mathrm{N}=12287 \\
\text { (interventio } \\
\mathrm{n}=6055, \\
\text { control = } \\
6232)\end{array}$ & $\begin{array}{l}\text { Tailored } \\
\text { feedback, self- } \\
\text { efficacy, goal } \\
\text { setting, social } \\
\text { support, } \\
\text { knowledge, } \\
\text { recommendatio } \\
\text { n }\end{array}$ & $\begin{array}{l}3 \text { months } \\
\text { and } 6 \\
\text { months } \\
\text { study } \\
\text { Monitoring } \\
\text { of everyday } \\
\text { activity, total } \\
\text { activity time, } \\
\text { strength } \\
\text { training, } \\
\text { physio } \\
\text { therapist } \\
\text { answered } \\
\text { question }\end{array}$ & $\begin{array}{l}\text { Reduction, } \\
\text { Tunnelling, } \\
\text { Tailoring, } \\
\text { Suggestion, } \\
\text { Social Role, } \\
\text { Trustworthiness, } \\
\text { Expertise, } \\
\text { Social Learning, } \\
\text { Social } \\
\text { Comparison, } \\
\text { Normative } \\
\text { Influence }\end{array}$ & $\begin{array}{l}\text { No significant } \\
\text { difference in } \\
\text { physical activity } \\
\text { between } \\
\text { intervention and } \\
\text { controlled group }\end{array}$ & $\begin{array}{l}\text { Non- } \\
\text { intervention } \\
\text { - control }\end{array}$ & $\begin{array}{l}\text { No blinding } \\
\text { Active users - } \\
\text { subsample of the } \\
\text { intervention group } \\
\text { results were assessed. }\end{array}$ \\
\hline
\end{tabular}




\begin{tabular}{|c|c|c|c|c|c|c|c|c|c|}
\hline 6 & A13 & $\begin{array}{l}\text { (Hurling et } \\
\text { al., 2007) }\end{array}$ & 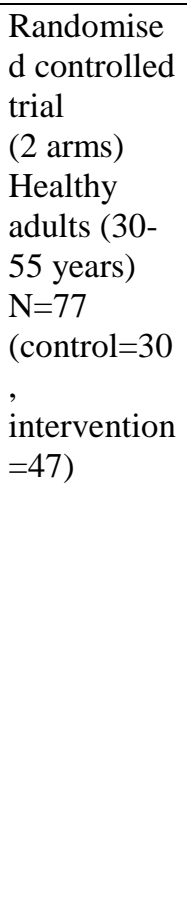 & $\begin{array}{l}\text { Goal-setting, } \\
\text { planning, } \\
\text { constructive } \\
\text { feedback, } \\
\text { monitoring, } \\
\text { habit forming, } \\
\text { reward }\end{array}$ & $\begin{array}{l}\text { Bluetooth } \\
\text { activated } \\
\text { watch } \\
\text { Offered } \\
\text { solution to } \\
\text { perceived } \\
\text { barriers, } \\
\text { advice, } \\
\text { Weekly } \\
\text { multimedia } \\
\text { content, } \\
\text { dialogue, } \\
\text { goal setting } \\
\text { or planning, } \\
\text { message } \\
\text { board, } \\
\text { motivational } \\
\text { tips, self- } \\
\text { assessment, } \\
\text { skills and } \\
\text { knowledge } \\
\text { questionnair } \\
\text { e }\end{array}$ & $\begin{array}{l}\text { Reduction, } \\
\text { Tunnelling, } \\
\text { Tailoring, } \\
\text { Self- } \\
\text { Monitoring, } \\
\text { Praise, } \\
\text { Reminders, } \\
\text { Suggestion, } \\
\text { Social Learning, } \\
\text { Social } \\
\text { Comparison, } \\
\text { Social } \\
\text { Facilitation }\end{array}$ & $\begin{array}{l}\text { Increases in } \\
\text { physical activity } \\
\text { and increased } \\
\text { weight loss were } \\
\text { seen in the } \\
\text { intervention } \\
\text { group. There is a } \\
\text { significant } \\
\text { different between } \\
\text { the } 2 \text { groups }\end{array}$ & $\begin{array}{l}\text { Waitlist } \\
\text { controlled } \\
\text { arm }\end{array}$ & Small sample size \\
\hline 7 & A18 & $\begin{array}{l}\text { (King, } \\
\text { 2013) }\end{array}$ & $\begin{array}{l}\text { Randomize } \\
\mathrm{d} \text { controlled } \\
\text { trial } \\
\text { ( } 2 \text { arms) } \\
\text { Inactive } \\
\text { adults } \\
\text { older, low } \\
\text { income, } \\
\mathrm{N}=40 \\
\text { (control=20 } \\
\text { intervention } \\
=20 \text { ) }\end{array}$ & $\begin{array}{l}\text { Problem solving } \\
\text { around barriers, } \\
\text { monitoring, } \\
\text { establish } \\
\text { personalised } \\
\text { goal, } \\
\text { understanding } \\
\text { the risk of } \\
\text { physical } \\
\text { inactivity, } \\
\text { committing } \\
\text { oneself, } \\
\text { substituting } \\
\text { more active } \\
\text { alternate, }\end{array}$ & $\begin{array}{l}4 \text { month } \\
\text { study } \\
\text { Virtual } \\
\text { advisor } \\
\text { Track daily } \\
\text { steps, } \\
\text { tailored } \\
\text { feedback, } \\
\text { action plan } \\
\text { based on the } \\
\text { pedometer } \\
\text { input, social } \\
\text { dialogue }\end{array}$ & $\begin{array}{l}\text { Tailoring, } \\
\text { Simulation, } \\
\text { Reminders, } \\
\text { Similarity, } \\
\text { Social Role, } \\
\text { Trustworthiness, } \\
\text { Expertise }\end{array}$ & $\begin{array}{l}\text { Increased walking } \\
\text { in virtual advisor } \\
\text { intervention. 130- } \\
135 \text { minutes per } \\
\text { week walking } \\
\text { difference } \\
\text { between groups }\end{array}$ & $\begin{array}{l}\text { Health } \\
\text { education } \\
\text { control }\end{array}$ & $\begin{array}{l}19 \text { item computer } \\
\text { credibility skill } \\
\text { Small sample size }\end{array}$ \\
\hline
\end{tabular}




\begin{tabular}{|c|c|c|c|c|c|c|c|c|c|}
\hline & & & & $\begin{array}{l}\text { rewarding, } \\
\text { reminding }\end{array}$ & & & & & \\
\hline 8 & A20 & $\begin{array}{l}\text { (Lau, et al, } \\
\text { 2012) }\end{array}$ & $\begin{array}{l}\text { Quasi } \\
\text { experiment } \\
\text { al study, } \\
\text { non- } \\
\text { randomised } \\
\mathrm{N}=78 \\
12-15 \\
\text { years old, } \\
\text { school } \\
\text { children } \\
\text { non- } \\
\text { randomly } \\
\text { assigned } \\
\text { (interventio } \\
\mathrm{n}=38, \\
\text { control } \\
=40 \text { ) }\end{array}$ & $\begin{array}{l}\text { Stage-matched } \\
\text { information, } \\
\text { behaviour skill } \\
\text { training, } \\
\text { reinforcement, } \\
\text { reward, goal- } \\
\text { setting }\end{array}$ & $\begin{array}{l}\text { Daily } \\
\text { tailored } \\
\text { SMS and } \\
\text { stage- } \\
\text { matched } \\
\text { internet } \\
\text { physical } \\
\text { activity } \\
\text { program } \\
\text { twice a week } \\
\text { for } 8 \text { weeks }\end{array}$ & $\begin{array}{l}\text { Tunnelling, } \\
\text { Tailoring, } \\
\text { Reminders, } \\
\text { Suggestion, } \\
\text { Similarity, } \\
\text { Social Role, } \\
\text { Trustworthiness, } \\
\text { Expertise, } \\
\text { Social Learning, } \\
\text { Social } \\
\text { Comparison, } \\
\text { Normative } \\
\text { Influence, } \\
\text { Social } \\
\text { Facilitation }\end{array}$ & $\begin{array}{l}\text { Significant } \\
\text { improvement in } \\
\text { Stage of } \\
\text { Motivational } \\
\text { Readiness group }\end{array}$ & $\begin{array}{l}\text { Stage- } \\
\text { matched } \\
\text { program/no } \\
\text { treatment }\end{array}$ & $\begin{array}{l}\text { Non-randomised } \\
\text { Descriptive statstics }\end{array}$ \\
\hline 9 & A21 & $\begin{array}{l}\text { (Migneault } \\
\text { et al., 2012) }\end{array}$ & $\begin{array}{l}\text { Randomise } \\
\mathrm{d} \text { controlled } \\
\text { trial of } \\
\text { multi- } \\
\text { behaviour } \\
\text { intervention } \\
\text { ( } 2 \text { arms }) \\
\text { urban } \\
\text { African-- } \\
\text { American } \\
\text { adults } \\
\mathrm{N}=337\end{array}$ & $\begin{array}{l}\text { Multi-behaviour } \\
\text { intervention }\end{array}$ & $\begin{array}{l}\text { Automated } \\
\text { telephone } \\
\text { calls over } 8 \\
\text { months, } \\
\text { assessments } \\
\text { every } 4 \\
\text { months for } 1 \\
\text { year }\end{array}$ & $\begin{array}{l}\text { Tailoring, } \\
\text { Reminders, } \\
\text { Suggestion, } \\
\text { Similarity, } \\
\text { Trustworthiness, } \\
\text { Expertise }\end{array}$ & $\begin{array}{l}\text { Improvement in } \\
\text { results noted }\end{array}$ & $\begin{array}{l}\text { Education } \\
\text { only control }\end{array}$ & Multivariate analysis \\
\hline 10 & A23 & $\begin{array}{l}\text { (Morgan et } \\
\text { al., 2013) }\end{array}$ & $\begin{array}{l}\text { Randomise } \\
\mathrm{d}, \\
\text { controlled } \\
\text { trial (multi } \\
\text { arm) } \\
\text { Overweight } \\
\text { \& Obese } \\
\text { men }\end{array}$ & $\begin{array}{l}\text { Goal setting, } \\
\text { self-monitoring }\end{array}$ & $\begin{array}{l}3 \text { month } \\
\text { intervention } \\
\text { duration } \\
\text { with } 6 \\
\text { month } \\
\text { assessment } \\
\text { One arm } \\
\text { Gender- } \\
\end{array}$ & $\begin{array}{l}\text { Tailoring, } \\
\text { Personalisation, } \\
\text { Self- } \\
\text { Monitoring, } \\
\text { Trustworthiness, } \\
\text { Expertise }\end{array}$ & $\begin{array}{l}\text { Significant } \\
\text { improvement } \\
\text { noted, lower } \\
\text { BMI, waist } \\
\text { circumference }\end{array}$ & $\begin{array}{l}\text { Control } \\
=\text { Waitlist }\end{array}$ & \\
\hline
\end{tabular}




\begin{tabular}{|c|c|c|c|c|c|c|c|c|c|}
\hline & & & $\begin{array}{l}\mathrm{N}=159 \\
\text { Resources } \\
(\mathrm{n}=54), \\
\text { online } \\
(\mathrm{n}=53), \\
\text { waitlist (52) }\end{array}$ & & $\begin{array}{l}\text { tailored } \\
\text { weight loss } \\
\text { materials } \\
\text { (DVD, } \\
\text { handbooks, } \\
\text { pedometer, } \\
\text { tape measure } \\
\text { Another } \\
\text { arm, } \\
\text { resources, } \\
\text { online, } \\
\text { feedback }\end{array}$ & & & & \\
\hline 11 & A24 & $\begin{array}{l}\text { (Mutsuddi, } \\
\text { 2012) }\end{array}$ & $\begin{array}{l}\text { Persuasive } \\
\text { power of } \\
\text { text } \\
\text { messages } \\
\text { study } \\
\text { College } \\
\text { students } \\
\mathrm{N}=42\end{array}$ & $\begin{array}{l}\text { Reminder, self- } \\
\text { monitoring }\end{array}$ & $\begin{array}{l}\text { Text } \\
\text { messages for } \\
2 \text { months } \\
\text { Source of } \\
\text { messages } \\
\text { (automated, } \\
\text { fitness } \\
\text { specialist, } \\
\text { family/friend } \\
\text { s) tailoring } \\
\text { (tailored } \\
\text { /non } \\
\text { tailored) } \\
\text { Followed by } \\
\text { interview }\end{array}$ & $\begin{array}{l}\text { Tailoring, Self- } \\
\text { Monitoring, } \\
\text { Praise, } \\
\text { Reminders, } \\
\text { Suggestion, } \\
\text { Social Role, } \\
\text { Social } \\
\text { Comparison, } \\
\text { Normative } \\
\text { Influence, } \\
\text { Social } \\
\text { Facilitation, } \\
\text { Cooperation }\end{array}$ & $\begin{array}{l}\text { Positive impact } \\
\text { noted }\end{array}$ & none & $\begin{array}{l}\text { There was no } \\
\text { controlled arm } \\
2 \times 3 \text { research design }\end{array}$ \\
\hline 12 & A25 & $\begin{array}{l}\text { ( Patrick et } \\
\text { al., 2011) }\end{array}$ & $\begin{array}{l}\text { Randomise } \\
\mathrm{d} \text { controlled } \\
\text { trial }(2 \\
\text { arms }) \\
\text { Overweight } \\
\text { or obese } \\
\text { men } \\
\mathrm{N}=441\end{array}$ & $\begin{array}{l}\text { Goal setting, } \\
\text { social support, } \\
\text { self efficacy } \\
\text { Web-based } \\
\text { assessment of } \\
\text { diet and } \\
\text { physical activity } \\
\text { behaviour }\end{array}$ & $\begin{array}{l}\text { Modules to } \\
\text { be } \\
\text { completed } \\
\text { weekly } \\
\text { addressing } \\
\text { weight- } \\
\text { related } \\
\text { behaviours } \\
\text { with } 6 \text { and } \\
12 \text { month } \\
\text { assessments }\end{array}$ & $\begin{array}{l}\text { Tunnelling, } \\
\text { Tailoring, } \\
\text { Personalisation, } \\
\text { Self- } \\
\text { Monitoring, } \\
\text { Simulation, } \\
\text { Reminders, } \\
\text { Suggestion, } \\
\text { Trustworthiness, } \\
\text { Expertise }\end{array}$ & $\begin{array}{l}\text { increase in } \\
\text { walking activity } \\
\text { in intervention } \\
\text { group but no } \\
\text { significant } \\
\text { differences } \\
\text { between groups, } \\
\text { however, } 35 \% \text { of } \\
\text { men in highest } \\
\text { tertile of goal } \\
\text { setting has poitive } \\
\text { outcome, lost at }\end{array}$ & $\begin{array}{l}\text { Intervention/ } \\
\text { delayed } \\
\text { treatment }\end{array}$ & $\begin{array}{l}\text { ANOVA } \\
\text { attrition }\end{array}$ \\
\hline
\end{tabular}




\begin{tabular}{|c|c|c|c|c|c|c|c|c|c|}
\hline & & & & & & & $\begin{array}{l}\text { least } 5 \% \text { of body } \\
\text { weight, increase } \\
\text { in understanding }\end{array}$ & & \\
\hline 13 & A26 & $\begin{array}{l}\text { ( Patrick et } \\
\text { al., 2014) }\end{array}$ & $\begin{array}{l}\text { Randomise } \\
\mathrm{d} \text { controlled } \\
\text { trial }(2 \\
\text { arms) } \\
\text { Overweight } \\
\text { or obese } \\
\text { college } \\
\text { students } \\
\mathrm{N}=404 \\
\text { Intervention } \\
\mathrm{n}=202) \\
\text { control } \\
(\mathrm{n}=202)\end{array}$ & $\begin{array}{l}\text { Self- } \\
\text { monitoring, } \\
\text { intention } \\
\text { formation, goal } \\
\text { setting, } \\
\text { feedback, self } \\
\text { efficacy, social } \\
\text { support, } \\
\text { tailoring }\end{array}$ & $\begin{array}{l}\text { Daily } \\
\text { contact with } \\
\text { one or more } \\
\text { web or } \\
\text { phone-based } \\
\text { Utilises } \\
\text { multiple } \\
\text { touchpoints: } \\
\text { Facebook, } \\
\text { text } \\
\text { messaging, } \\
\text { apps, blogs } \\
\text { and email } \\
\text { after } 2 \text { years }\end{array}$ & $\begin{array}{l}\text { Tunnelling, } \\
\text { Tailoring, Self- } \\
\text { Monitoring, } \\
\text { Rewards, } \\
\text { Reminders, } \\
\text { Suggestion, } \\
\text { Social Role, } \\
\text { Trustworthiness, } \\
\text { Expertise, } \\
\text { Authority, Third } \\
\text { Party } \\
\text { Endorsements, } \\
\text { Verifiability, } \\
\text { Social Learning, } \\
\text { Social } \\
\text { Comparison, } \\
\text { Normative } \\
\text { Influence, } \\
\text { Social } \\
\text { Facilitation, } \\
\text { Cooperation, } \\
\text { Competition, } \\
\text { Recognition }\end{array}$ & $\begin{array}{l}\text { Differences were } \\
\text { significant in } 6 \\
\text { months and } 12 \\
\text { months but not } \\
\text { significant in } 18 \\
\text { months and } 24 \\
\text { months. }\end{array}$ & information & $\begin{array}{l}\text { Large sample, } \\
\text { ethinically diverse } \\
\text {,retention- high }\end{array}$ \\
\hline 14 & A27 & $\begin{array}{l}\text { (Peels et al., } \\
\text { 2013) }\end{array}$ & $\begin{array}{l}\text { Randomise } \\
\mathrm{d} \\
\text { intervention } \\
\text { Dutch } \\
\text { adults (50+ } \\
\text { years) } \\
\mathrm{N}=1729 \\
\text { (basic } \\
\text { printed, } \\
\text { basic web } \\
\text { based, } \\
\text { printed } \\
\text { environmen }\end{array}$ & $\begin{array}{l}\text { Same behaviour } \\
\text { change principle } \\
\text { delivered in } \\
\text { different } \\
\text { medium } \\
\text { Tailored } \\
\text { information, } \\
\text { feedback } \\
\text { Motivation, } \\
\text { awareness, } \\
\text { active learning, } \\
\text { action plan }\end{array}$ & $\begin{array}{l}3 \\
\text { interventions } \\
\text { via tailored } \\
\text { communicati } \\
\text { on in } 4 \\
\text { months with } \\
\text { assessment } \\
3,6 \& 12 \\
\text { months after } \\
\text { baseline was } \\
\text { established }\end{array}$ & $\begin{array}{l}\text { Tunnelling, } \\
\text { Tailoring, Self- } \\
\text { Monitoring, } \\
\text { Simulation, } \\
\text { Praise, } \\
\text { Reminders, } \\
\text { Suggestion, } \\
\text { Trustworthiness, } \\
\text { Expertise, } \\
\text { Authority, Third } \\
\text { Party } \\
\text { Endorsements, } \\
\text { Verifiability }\end{array}$ & $\begin{array}{l}\text { Printed and wb- } \\
\text { based intervention } \\
\text { equally effective }\end{array}$ & $\begin{array}{l}\text { Printed } \\
\text { information } \\
\text { for control } \\
\text { group }\end{array}$ & $\begin{array}{l}\text { Intervention } \\
\text { component used } \\
\text { measures } \\
\text { ANOVA } \\
\mathrm{P}<0.008 \\
\text { Recall bias }\end{array}$ \\
\hline
\end{tabular}




\begin{tabular}{|c|c|c|c|c|c|c|c|c|c|}
\hline & & & $\begin{array}{l}\text { tal printed } \\
\text { web based } \\
\text { intervention }\end{array}$ & & & & & & \\
\hline 15 & A30 & $\begin{array}{l}\text { (Reid et al., } \\
\text { 2012) }\end{array}$ & $\begin{array}{l}\text { Randomise } \\
\mathrm{d} \text { controlled } \\
\text { trial } \\
(2 \text { arms }) \\
\text { Adults } \\
(20-80 \\
\text { years) } \\
\mathrm{N}=223 \\
\text { (control } \\
=108, \\
\text { intervention } \\
=115)\end{array}$ & $\begin{array}{l}\text { self-control } \\
\text {,planning, goal- } \\
\text { setting, } \\
\text { monitoring and } \\
\text { self-regulation }\end{array}$ & $\begin{array}{l}6 \text { month } \\
\text { intervention } \\
\text { with } \\
\text { personally } \\
\text { tailored } \\
\text { program and } \\
\text { access to a } \\
\text { website, } 5 \\
\text { online } \\
\text { tutorials, } 2 \text {, } \\
4,8,14 \\
\text { weeks }\end{array}$ & $\begin{array}{l}\text { Tunnelling, } \\
\text { Tailoring, } \\
\text { Personalisation, } \\
\text { Self- } \\
\text { Monitoring, } \\
\text { Simulation, } \\
\text { Praise, } \\
\text { Reminders, } \\
\text { Suggestion, } \\
\text { Trustworthiness, } \\
\text { Expertise }\end{array}$ & $\begin{array}{l}\text { Significantly } \\
\text { increased physical } \\
\text { activity resulted } \\
\text { in intervention } \\
\text { group }\end{array}$ & $\begin{array}{l}\text { received } \\
\text { information } \\
\text { from the } \\
\text { physician } \\
\text { and the } \\
\text { booklet, } \\
\text { email } \\
\text { contact }\end{array}$ & High attrition \\
\hline 16 & A32 & $\begin{array}{l}\text { (Rothert et } \\
\text { al., 2006) }\end{array}$ & $\begin{array}{l}\text { Randomise } \\
\text { d controlled } \\
\text { trial }(2 \\
\text { arms) } \\
\mathrm{N}=2862 \\
\text { Intervention } \\
\text { Overweight } \\
\text { and obese } \\
\text { people with } \\
\text { a BMI } \\
\text { between } 27 \\
\text { to } 40 \mathrm{~kg} / \mathrm{m} 2 \\
(\mathrm{~N}=1475), \\
\text { control }\end{array}$ & $\begin{array}{l}\text { Action } \\
\text { planning, Social } \\
\text { support, self- } \\
\text { monitoring }\end{array}$ & $\begin{array}{l}\text { Expert } \\
\text { system } \\
6 \text { weeks with } \\
\text { follow up at } \\
6 \& 12 \\
\text { months } \\
\text { Online } \\
\text { tailored } \\
\text { advice, } \\
\text { email } \\
\text { reminders to } \\
\text { complete } \\
\text { questionnair } \\
\text { es about } \\
\text { progress and } \\
\text { achievement } \\
\text { s }\end{array}$ & $\begin{array}{l}\text { Tunnelling, } \\
\text { Tailoring, Self- } \\
\text { Monitoring, } \\
\text { Simulation, } \\
\text { Reminders, } \\
\text { Suggestion, } \\
\text { Trustworthiness, } \\
\text { Expertise }\end{array}$ & $\begin{array}{l}\text { Participants using } \\
\text { the tailored } \\
\text { behavioural } \\
\text { weight } \\
\text { management } \\
\text { program } \\
\text { experienced } \\
\text { significant weight } \\
\text { loss }\end{array}$ & $\begin{array}{l}\text { Information } \\
\text { only }\end{array}$ & $\begin{array}{l}\text { ANOVA method } \\
\text { Missing data } \\
\text { considered } \\
\text { Reliance of self- } \\
\text { reported data }\end{array}$ \\
\hline 17 & A33 & $\begin{array}{l}\text { (Schulz et } \\
\text { al., 2014) }\end{array}$ & $\begin{array}{l}\text { Randomise } \\
\text { d controlled } \\
\text { trial 18-65 } \\
\text { years with } \\
\text { computer } \\
\end{array}$ & $\begin{array}{l}\text { Planning, } \\
\text { monitoring, } \\
\text { normative } \\
\text { feedback }\end{array}$ & $\begin{array}{l}\text { Sequential, } \\
\text { simultaneous } \\
\text { and } \\
\text { controlled } \\
\text { tailoring, } \\
\end{array}$ & $\begin{array}{l}\text { Tunnelling, } \\
\text { Self- } \\
\text { Monitoring, } \\
\text { Simulation, } \\
\text { Praise, } \\
\end{array}$ & $\begin{array}{l}\text { Five lifestyle } \\
\text { behaviours were } \\
\text { targeted and } \\
\text { changed over } \\
\text { time. Physical }\end{array}$ & $\begin{array}{l}\text { Control } \\
\text { group } \\
\text { receive } \\
\text { feedback on }\end{array}$ & \\
\hline
\end{tabular}




\begin{tabular}{|c|c|c|c|c|c|c|c|c|c|}
\hline & & & $\begin{array}{l}\text { and internet } \\
\text { access } \\
\text { Sequential } \\
\mathrm{N}=1736, \\
\text { simultaneou } \\
\mathrm{s}=1638, \\
\text { control } \\
=1681\end{array}$ & & $\begin{array}{l}\text { Follow up at } \\
12 \text { months } \\
\text { and } 24 \\
\text { months }\end{array}$ & $\begin{array}{l}\text { Reminders, } \\
\text { Trustworthiness, } \\
\text { Expertise, } \\
\text { Social } \\
\text { Comparison }\end{array}$ & $\begin{array}{l}\text { activity is one of } \\
\text { them, }\end{array}$ & $\begin{array}{l}\text { initial health } \\
\text { assessment }\end{array}$ & \\
\hline 19 & A36 & $\begin{array}{l}\text { (Steinberg, } \\
\text { Levine, } \\
\text { Askew, } \\
\text { Foley, \& } \\
\text { Bennett, } \\
\text { 2013) }\end{array}$ & $\begin{array}{l}\text { Randomise } \\
\mathrm{d} \text { controlled } \\
\text { trial (2 } \\
\text { arms) } \\
\text { Racial and } \\
\text { ethnically } \\
\text { minor } \\
\text { women (25- } \\
50 \text { years) } \\
\text { with BMI } \\
\text { greater than } \\
\text { or equal to } \\
25 \mathrm{~kg} / \mathrm{m}^{2}\end{array}$ & $\begin{array}{l}\text { Goal setting, } \\
\text { self-monitoring } \\
\text { of behavioural } \\
\text { goals, regular } \\
\text { feedback }\end{array}$ & $\begin{array}{l}6 \text { months } \\
\text { follow up } \\
\text { study } \\
\text { Monitor goal } \\
\text { daily for } 12 \\
\text { weeks, } \\
\text { walking goal }\end{array}$ & $\begin{array}{l}\text { Tailoring, Self- } \\
\text { Monitoring, } \\
\text { Simulation, } \\
\text { Praise, } \\
\text { Reminders, } \\
\text { Suggestion, } \\
\text { Trustworthiness, } \\
\text { Expertise }\end{array}$ & $\begin{array}{l}\text { Greater adherence } \\
\text { to text messaging } \\
\text { associated with } \\
\text { greater weight } \\
\text { loss }\end{array}$ & $\begin{array}{l}\text { Education } \\
\text { control }\end{array}$ & $\begin{array}{l}\text { Pilot study, small } \\
\text { sample size }\end{array}$ \\
\hline
\end{tabular}




\begin{tabular}{|c|c|c|c|c|c|c|c|c|c|}
\hline & & & $\begin{array}{l}\mathrm{N}=50 \\
\text { (control=24 } \\
\text { intervention } \\
=26)\end{array}$ & & & & & & \\
\hline 20 & A38 & $\begin{array}{l}\text { (Winett, } \\
\text { Anderson, } \\
\text { Wojcik, } \\
\text { Winett, \& } \\
\text { Bowden, } \\
\text { 2007) }\end{array}$ & 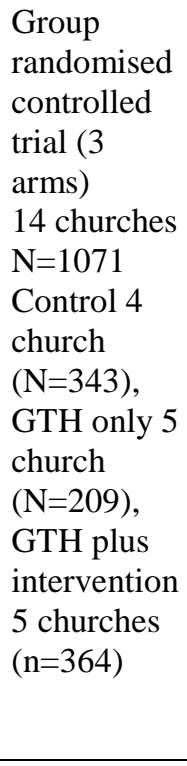 & $\begin{array}{l}\text { Goal setting, } \\
\text { Monitoring, } \\
\text { social support, }\end{array}$ & $\begin{array}{l}\text { Weekly for } \\
12 \text { weeks } \\
\text { with } 6 \\
\text { month } \\
\text { follow up } \\
\text { Web-based } \\
\text { video- } \\
\text { delivered } \\
\text { information } \\
\& \text { self- } \\
\text { regulation } \\
\text { strategies } \\
\text { with weekly } \\
\text { goal-setting } \\
\& \text { future } \\
\text { planning } \\
\text { followed by } \\
\text { positive } \\
\text { feedback }\end{array}$ & $\begin{array}{l}\text { Tunnelling, } \\
\text { Tailoring, Self- } \\
\text { Monitoring, } \\
\text { Simulation, } \\
\text { Praise, Rewards, } \\
\text { Reminders, } \\
\text { Trustworthiness, } \\
\text { Expertise } \\
\text { Social learning, } \\
\text { Social } \\
\text { comparison, } \\
\text { Normative } \\
\text { influence, } \\
\text { Social } \\
\text { facilitation, } \\
\text { Cooperation }\end{array}$ & $\begin{array}{l}\text { Internet based } \\
\text { intervention } \\
\text { together with the } \\
\text { environmental } \\
\text { social support } \\
\text { may improve } \\
\text { outcomes for } \\
\text { participants }\end{array}$ & wait list & $\begin{array}{l}\text { Large sample size, } \\
>80 \% \text { follow up }\end{array}$ \\
\hline
\end{tabular}

Table: 5: Studies and their effectiveness 